University of New Hampshire

University of New Hampshire Scholars' Repository

Faculty Publications

7-21-2009

\title{
Soil-Atmosphere Exchange of Nitrous Oxide, Nitric Oxide, Methane, and Carbon Dioxide in Logged and Undisturbed Forest in the Tapajos National Forest, Brazil
}

\author{
Michael Keller \\ USDA Forest Service \\ Ruth K. Varner \\ University of New Hampshire, Durham, ruth.varner@unh.edu \\ Jadson D. Dias \\ Fundação Floresta Tropical \\ Hudson Silva \\ University of New Hampshire, Durham \\ Patrick M. Crill \\ Stockholm University \\ Follow this and additional works at: https://scholars.unh.edu/faculty_pubs \\ eernextentse for additional authors
}

This is an article published by American Meteorological Society in Earth Interactions in 2009, available online:

https://dx.doi.org/10.1175/El125.1

\section{Recommended Citation}

Keller, M., R.K. Varner, J.D. Dias, ${ }^{\circ} H$. Silva, P.M. Crill, R.C. de Oliveira Jr. and G.P. Asner (2005), SoilAtmosphere Exchange of Nitrous Oxide, Nitric Oxide, Methane, and Carbon Dioxide in Logged and Undisturbed Forest in the Tapajos National Forest, Brazil, Earth Interactions: LBA Special Issue, 9 (23), 1-28.

This Article is brought to you for free and open access by University of New Hampshire Scholars' Repository. It has been accepted for inclusion in Faculty Publications by an authorized administrator of University of New Hampshire Scholars' Repository. For more information, please contact Scholarly.Communication@unh.edu. 


\section{Authors}

Michael Keller, Ruth K. Varner, Jadson D. Dias, Hudson Silva, Patrick M. Crill, Raimundo Cosme de Oliveira Jr., and Gregory P. Asner 


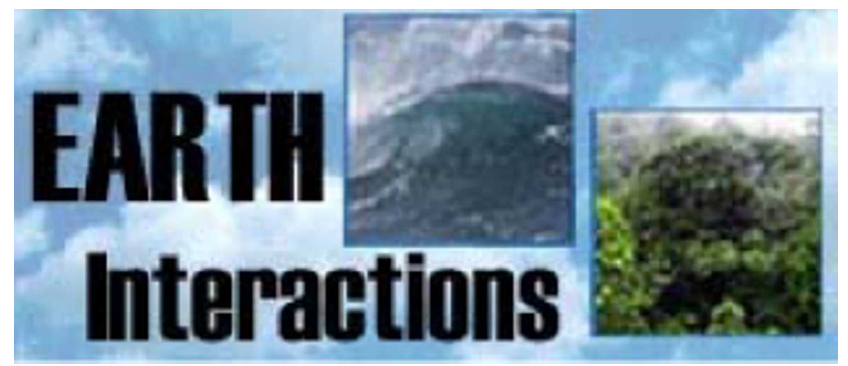

Copyright $($ C) 2005, Paper 09-023; 12,248 words, 5 Figures, 0 Animations, 6 Tables. http://EarthInteractions.org

\section{Soil-Atmosphere Exchange of Nitrous Oxide, Nitric Oxide, Methane, and Carbon Dioxide in Logged and Undisturbed Forest in the Tapajos National Forest, Brazil}

\section{Michael Keller*}

International Institute of Tropical Forestry, USDA Forest Service, San Juan, Puerto Rico, and Complex System Research Center, Institute for the Study of Earth, Oceans, and Space, University of New Hampshire, Durham, New Hampshire

\section{Ruth Varner}

Complex System Research Center, Institute for the Study of Earth, Oceans, and Space, University of New Hampshire, Durham, New Hampshire

\section{Jadson D. Dias}

Fundação Floresta Tropical, Santarém, Pará, Brazil

\section{Hudson Silva}

Complex System Research Center, Institute for the Study of Earth, Oceans, and Space, University of New Hampshire, Durham, New Hampshire, and Fundação Floresta Tropical, Santarém, Pará, Brazil

* Corresponding author address: Michael Keller, CSRC Morse Hall, University of New Hampshire, 39 College Rd., Durham, NH 03824.

E-mail address: michael.keller@unh.edu 
Earth Interactions - Volume 9 (2005) - Paper No. 23 - Page 2

\title{
Patrick Crill
}

Complex System Research Center, Institute for the Study of Earth, Oceans, and Space, University of New Hampshire, Durham, New Hampshire, and Department of Geology and Geochemistry, Stockholm University, Stockholm, Sweden

\section{Raimundo Cosme de Oliveira Jr.}

EMBRAPA Amazônia Oriental, Belém, Para, Brazil

\section{Gregory P. Asner}

Department of Global Ecology, Carnegie Institution of Washington, Stanford University, Stanford, California

Received 31 August 2004; accepted 28 February 2005

\begin{abstract}
Selective logging is an extensive land use in the Brazilian Amazon region. The soil-atmosphere fluxes of nitrous oxide $\left(\mathrm{N}_{2} \mathrm{O}\right)$, nitric oxide (NO), methane $\left(\mathrm{CH}_{4}\right)$, and carbon dioxide $\left(\mathrm{CO}_{2}\right)$ are studied on two soil types (clay Oxisol and sandy loam Ultisol) over two years (2000-01) in both undisturbed forest and forest recently logged using reduced impact forest management in the Tapajos National Forest, near Santarem, Para, Brazil. In undisturbed forest, annual soil-atmosphere fluxes of $\mathrm{N}_{2} \mathrm{O}$ (mean \pm standard error) were $7.9 \pm 0.7$ and $7.0 \pm 0.6 \mathrm{ng} \mathrm{N} \mathrm{cm}{ }^{-2} \mathrm{~h}^{-1}$ for the Oxisol and $1.7 \pm 0.1$ and $1.6 \pm 0.3 \mathrm{ng} \mathrm{N} \mathrm{cm}^{-2} \mathrm{~h}^{-1}$ for the Ultisol for 2000 and 2001, respectively. The annual fluxes of NO from undisturbed forest soil in 2001 were $9.0 \pm 2.8 \mathrm{ng} \mathrm{N}$ $\mathrm{cm}^{-2} \mathrm{~h}^{-1}$ for the Oxisol and $8.8 \pm 5.0 \mathrm{ng} \mathrm{N} \mathrm{cm}{ }^{-2} \mathrm{~h}^{-1}$ for the Ultisol. Consumption of $\mathrm{CH}_{4}$ from the atmosphere dominated over production on undisturbed forest soils. Fluxes averaged $-0.3 \pm 0.2$ and $-0.1 \pm 0.9 \mathrm{mg} \mathrm{CH}_{4} \mathrm{~m}^{-2}$ day $^{-1}$ on the Oxisol and $-1.0 \pm 0.2$ and $-0.9 \pm 0.3 \mathrm{mg} \mathrm{CH}_{4} \mathrm{~m}^{-2}$ day $^{-1}$ on the Ultisol for years 2000 and 2001. For $\mathrm{CO}_{2}$ in 2001, the annual fluxes averaged $3.6 \pm 0.4 \mu \mathrm{mol} \mathrm{m} \mathrm{m}^{-2} \mathrm{~s}^{-1}$ on the Oxisol and $4.9 \pm 1.1 \mu \mathrm{mol} \mathrm{m} \mathrm{m}^{-2} \mathrm{~s}^{-1}$ on the Ultisol. We measured fluxes over one year each from two recently logged forests on the Oxisol in 2000 and on the Ultisol in 2001. Sampling in logged areas was stratified from greatest to least ground disturbance covering log decks, skid trails, tree-fall gaps, and forest matrix. Areas of strong soil compaction, especially the skid trails and logging decks, were prone to significantly greater emissions of $\mathrm{N}_{2} \mathrm{O}, \mathrm{NO}$, and especially $\mathrm{CH}_{4}$. In the case of $\mathrm{CH}_{4}$, estimated annual emissions from decks reached extremely high rates of $531 \pm 419$ and $98 \pm 41 \mathrm{mg} \mathrm{CH}_{4} \mathrm{~m}^{-2}$ day $^{-1}$, for Oxisol and Ultisol sites, respectively, comparable to wetland emissions in the region. We calculated excess fluxes from logged areas by subtraction of a background forest matrix or undisturbed forest flux and adjusted these fluxes for the proportional area of ground disturbance. Our calculations suggest that selective logging increases emissions of $\mathrm{N}_{2} \mathrm{O}$ and $\mathrm{NO}$ from $30 \%$ to $350 \%$ depending upon conditions. While undisturbed forest was a $\mathrm{CH}_{4}$ sink, logged forest tended to emit methane at moderate rates. Soil-atmosphere $\mathrm{CO}_{2}$ fluxes were only slightly affected by logging. The regional effects of logging cannot be simply extrapolated based upon one site. We studied sites where reduced impact harvest management was used while in
\end{abstract}


Earth Interactions - Volume 9 (2005) - Paper No. 23 • Page 3

typical conventional logging ground damage is twice as great. Even so, our results indicate that for $\mathrm{N}_{2} \mathrm{O}, \mathrm{NO}$, and $\mathrm{CH}_{4}$, logging disturbance may be as important for regional budgets of these gases as other extensive land-use changes in the Amazon such as the conversion of forest to cattle pasture.

KEYWORDS: Selective logging; Trace gas; Tropical forest

\section{Introduction}

Selective logging is an extensive land use in the Amazon region of Brazil and in other tropical forest areas. According the Brazilian Institute for Geography and Statistics (IBGE), the volume of round-wood production in the Brazilian Amazon between 1991 and 2000 was $3.5 \times 10^{7} \mathrm{~m}^{3} \mathrm{yr}^{-1}$ (http://www.igbe.br/). Assuming a nominal harvest volume between 20 and $30 \mathrm{~m}^{3} \mathrm{ha}^{-1}$ this implies that in an average year approximately $1.8 \times 10^{6}$ to $1.2 \times 10^{6}$ ha were affected by logging during the 1990s. Based on a survey of sawmills conducted in 1996-97, Nepstad et al.

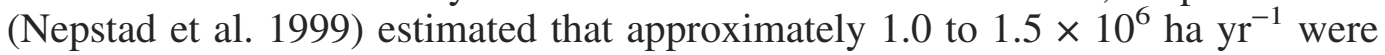
logged. The area of forest selectively logged each year in the Brazilian Amazon is similar to the area of forest cleared for pastoral and agricultural uses (Houghton et al. 2000).

Selective logging in the Brazilian Amazon generally involves felling and yarding (transport of timber from the cut site to the roadside) of 1-9 trees $\mathrm{ha}^{-1}$. Although relatively few trees are intentionally felled, selective logging causes substantial damage to the remaining forest stand (Ewel and Conde 1980). In the Brazilian Amazon in the municipality of Paragominas, Para, Verissimo et al. (Verissimo et al. 1992) found that on average 27 trees were damaged for each tree harvested and $38 \%$ of the canopy was destroyed at a harvest intensity of 6.4 trees $\mathrm{ha}^{-1}\left(38 \mathrm{~m}^{3} \mathrm{ha}^{-1}\right)$. Ground damage can also be severe. Johns et al. (Johns et al. 1996) found that in unplanned operations in Paragominas, approximately $15 \%$ of the ground area was affected by heavy machinery when 5.6 trees ha ${ }^{-1}$ were harvested $\left(30 \mathrm{~m}^{3} \mathrm{ha}^{-1}\right)$. Logging damage depends upon the logging practices employed. Also, working in the Paragominas municipality, Pereira et al. (Pereira et al. 2002) found that both ground damage and canopy damage could be reduced by about 50\% under reduced impact logging (RIL) harvest management compared to conventional logging (CL) practice.

Soil-atmosphere exchange of carbon dioxide $\left(\mathrm{CO}_{2}\right)$, nitric oxide (NO), nitrous oxide $\left(\mathrm{N}_{2} \mathrm{O}\right)$, and methane $\left(\mathrm{CH}_{4}\right)$ is controlled by complex biogeochemical processes (Conrad 1996). Tropical forests have high rates of biological productivity and rapid decomposition rates of organic matter because of abundant solar radiation, high temperature, and heavy precipitation. High nitrogen availability coupled with high moisture content makes tropical forest soils especially likely to emit $\mathrm{N}_{2} \mathrm{O}$ and $\mathrm{NO}$ (Davidson et al. 2000). The soils of tropical forests are globally important sources of both $\mathrm{N}_{2} \mathrm{O}$ and NO (Matson and Vitousek 1990; Davidson and Kingerlee 1997). Well-drained upland soils generally consume $\mathrm{CH}_{4}$ from the atmosphere and soil moisture content regulates the flux through its control on the diffusion of $\mathrm{CH}_{4}$ into the soil (Crill 1991; Born et al. 1990). Tropical forest soils can change from a sink to a source of $\mathrm{CH}_{4}$ depending upon soil moisture conditions and land use (Keller et al. 1990; Keller and Reiners 1994; Steudler et al. 1996). 
Earth Interactions - Volume 9 (2005) - Paper No. 23 • Page 4

Selective logging affects the forest canopy, microclimate, soil physical conditions, and biogeochemical cycling (Pereira et al. 2002; McNabb et al. 1997; Brouwer 1996). We asked whether these changes would affect carbon dioxide $\left(\mathrm{CO}_{2}\right)$, nitric oxide (NO), nitrous oxide $\left(\mathrm{N}_{2} \mathrm{O}\right)$, and methane $\left(\mathrm{CH}_{4}\right)$ exchange between forest soils and the atmosphere. We measured soil-atmosphere flux of these four trace gases on both Ultisol and Oxisol soils in both undisturbed and logged forests over two full years.

\section{Methods}

\subsection{Site description}

We conducted our study in the Tapajos National Forest (TNF) near km 83 on the Santarem-Cuiaba Highway $\left(3.04^{\circ} \mathrm{S}, 54.95^{\circ} \mathrm{W}\right)$ south of Santarem, Para, Brazil. The Brazilian Institute for the Environment and Renewable Resources (IBAMA) administered a demonstration logging project at this site. Logging by a commercial enterprise began in December 1999. Only one 100-ha survey and management block (quad 2, block 3) was harvested in the TNF during 1999 because of a delayed start in operations. In 2000, nearly 1000 ha were logged by the commercial operator. In 2000 we measured trace gas fluxes in the 100-ha block that was harvested in December 1999. In 2001, we made measurements on a second 100-ha block (quad 2, block 9) that had been logged in September 2000.

The TNF receives approximately $2000 \mathrm{~mm}$ of precipitation per year and has an annual mean temperature of $25^{\circ} \mathrm{C}$ (Silver et al. 2000). The rainy season extends from late December or early January through June. The duration of the rainy period varies from year to year. For purposes of comparison, we consider January through June the rainy period. Most logging operations are conducted in the dry season from July through December. Vegetation at the site is evergreen, mature tropical forest with a total biomass of about $372 \mathrm{Mg} \mathrm{ha}^{-1}$ (Keller et al. 2001). The most common timber species harvested during 2000 were Manilkara huberi, Carapa guianensis, Couratari guianensis, Licaria brasiliensis, and Nectandra rubra. The most common tree species [ $>35 \mathrm{~cm}$ diameter at breast height $(\mathrm{DBH})]$ found are Pouteria sp., Manilkara huberi, Carapa guianensis, Eschweilera sp., and Sclerolobium melanocarpum. The study site is located on an old, nearly flat, erosional remnant plateau with well-drained soils. We located our undisturbed forest measurements on contrasting soils, a clay-textured Oxisol (80\% clay, $18 \%$ sand, $2 \%$ silt in $0-10 \mathrm{~cm})$ and a sandy-loam-textured Ultisol $(60 \%$ sand, $38 \%$ clay, $2 \%$ silt in $0-10 \mathrm{~cm}$ ) (Silver et al. 2000). Both soils $(0-10 \mathrm{~cm})$ were acid with a pH of about 3.9 and 4.2 in the Ultisol and Oxisol, respectively. The soils had similar total $\mathrm{C}$ of about $2.5 \%$ in the top $10 \mathrm{~cm}$. The Ultisol had slightly less total $\mathrm{N}$ in the top $10 \mathrm{~cm}(0.14 \%)$ as compared to the Oxisol (0.18\%) (Silver et al. 2000). The logging operation studied in 1999 was located on the clay-textured Oxisol. In 2000, we studied logging on an Ultisol similar to the undisturbed forest site.

Within a selectively logged area, the degree of soil compaction and modification of microclimate and biogeochemical processes varies greatly according to harvest practice. Within the studied logging sites at TNF, we stratified sampling according to decreasing damage intensity from logging decks, skid trails, felling gaps to relatively undisturbed forest (Figure 1). Excluding roads where we did not sample 


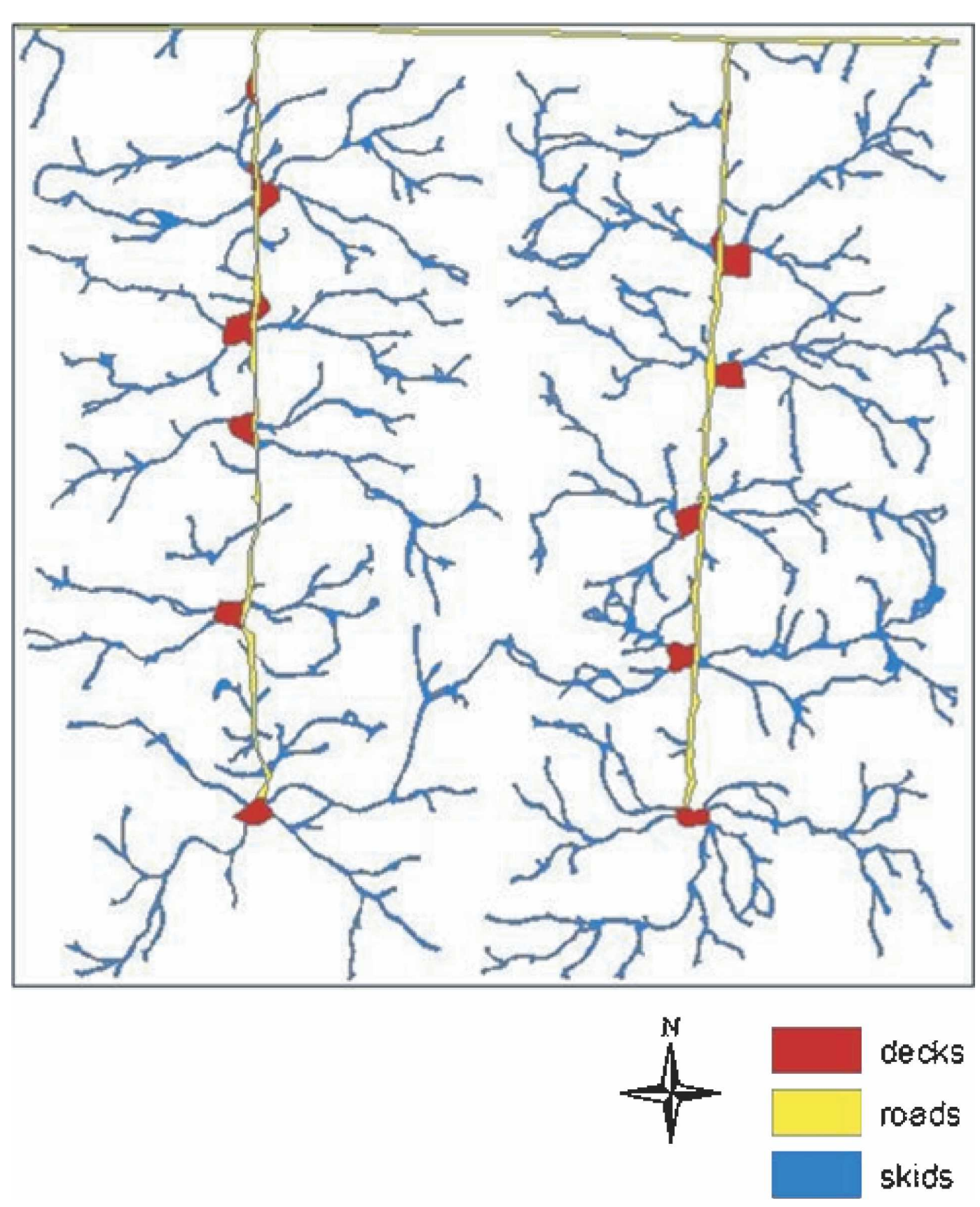

Figure 1. Map of mechanical soil disturbance (roads, decks, and skid trails) in a 100-ha forest area at the Tapajos National Forest logged in Dec 1999.

gas fluxes, the greatest damage was found on the log storage decks (or landings). Logs were skidded to these locations and stored prior to loading on trucks for transport to the mill. On decks, all vegetation was removed and the soil was compacted as a result of frequent passes of skidding and loading machinery. Decks were cleared by a tracked bulldozer so topsoil and organic matter were scraped off. 
Earth Interactions • Volume 9 (2005) • Paper No. 23 • Page 6

In the logging operations at TNF, articulated wheeled skidders were used to skid $\operatorname{logs}$ to the decks. Because logging at this site was planned, skid trails covered the logging blocks in a dendritic pattern (Figure 1). The primary skids were the central stems of the trail system. Secondary skids were the branches. In this planned system, many more trips were made along primary skid trails than along secondary trails. The tree-fall gap (hereafter gap) was the ground area where the harvest tree and collaterally damaged trees fell. This zone was extremely heterogeneous. In places it was characterized by bare soil while in other places it was covered by tangles $2 \mathrm{~m}$ or more high of fine and coarse debris. Areas within the logging block that were not decks, skid trails, or gaps were considered forest matrix. Holmes et al. (Holmes et al. 2002) and Pereira et al. (Pereira et al. 2002) provide more details on forest harvest practices and logging damage for a similar site in eastern Para.

\subsection{Field sampling of soil gas flux}

Undisturbed forest sites were sampled on 31 dates from 4 February 2000 through 26 February 2002. Measurements of soil-atmosphere flux for $\mathrm{N}_{2} \mathrm{O}$ and $\mathrm{CH}_{4}$ as well as soil water-filled pore space (WFPS) covered this full period, while measurements of fluxes of $\mathrm{NO}$ and $\mathrm{CO}_{2}$ commenced on 10 October 2000 and continued through the end of the study period. The Oxisol and Ultisol sites were sampled on the same day, generally between 0800 and 1800 local time. When all systems were operational, fluxes for all four gases were measured from eight chambers at randomly selected points along 30-m transects. After gas flux sampling was completed, soil samples were removed from each gas sampling location for determination of soil moisture content.

For the logging sites, in 2000, we randomly selected a focal site that we sampled approximately monthly. At that site, we measured fluxes in four sampling strata: the focal deck, adjacent skid trails, gaps, and background forest matrix areas. We defined the forest matrix as those areas more than $10 \mathrm{~m}$ distant from decks, skid trails, and gaps. Skid trail measurements were alternated between primary and secondary skid trails. On other dates, we made measurements at other randomly selected sites. In the first half (wet season) of 2000, these additional measurements were purposely biased toward decks and skid trails. On each sampling date, flux chamber locations within each stratum were randomly selected along 30-m transects in a manner similar to their selection within the undisturbed forest. For skid trails, transects were aligned diagonally across the trails in order to cross the tire ruts and the raised area between the ruts.

We sampled gas fluxes using enclosures consisting of a section of polyvinylchloride pipe $(0.25-\mathrm{m}$ diameter) that served as a base and an acrylonitrilebutadiene-styrene cap that fit snugly on the base. The combination of base plus cap was nearly cylindrical with a height of about $20 \mathrm{~cm}$ when inserted into the soil. Bases were inserted at most $30 \mathrm{~min}$ prior to flux measurements and they were removed immediately after completion of flux measurements in order to avoid artifacts related to root mortality from chamber insertion (Keller et al. 2000; Varner et al. 2003). Dynamic open chambers were used for measurement of NO and $\mathrm{CO}_{2}$ (Varner et al. 2003), and static vented chambers were used for measurements of $\mathrm{N}_{2} \mathrm{O}$ and $\mathrm{CH}_{4}$ (Keller and Reiners 1994). The measurement of these two pairs of gases was sequential, in a haphazard order, after lifting the chamber top to equilibrate the head space with ambient air. 
Earth Interactions - Volume 9 (2005) - Paper No. 23 • Page 7

\subsection{Field analytical system for $\mathrm{NO}$ and $\mathrm{CO}_{2}$}

We used an integrated flow system to measure $\mathrm{NO}$ and $\mathrm{CO}_{2}$. The chamber flow rate was regulated to about $300 \mathrm{~cm}^{3} \mathrm{~min}^{-1}$. Air entered the chamber through a chimney-like air gap that was specifically designed to minimize exchange with the outside air and to avoid pressure fluctuations within the chamber (Rayment and Jarvis 1997). Using this design, the pressure differential between the chamber and the outside air was less than $0.004 \mathrm{~Pa}$ in laboratory tests. The chamber base was capped for 3 to $10 \mathrm{~min}$.

Air flowed from the soil enclosure through a Teflon-lined polyethylene sample line $30 \mathrm{~m}$ in length and then it entered an infrared gas analyzer (Li-Cor 6262) for $\mathrm{CO}_{2}$ measurement. From the Li-6262, the sampled air then passed through a flow control manifold where it was mixed with a makeup airflow of about $1200 \mathrm{~cm}^{3}$ $\min ^{-1}$ and a flow of NO $(1 \mathrm{ppm})$ in oxygen-free nitrogen standard gas that varied from 3 to $10 \mathrm{~cm}^{3} \mathrm{~min}^{-1}$ as measured on an electronic mass flowmeter (Sierra Top-Trak). The flowmeter was checked occasionally against a NIST-traceable electronic bubble flowmeter (Gilibrator). The makeup air and standard additions maintained optimum and linear performance of the $\mathrm{NO}_{2}$ chemiluminescent analyzer (Scintrex LMA-3) according to the manufacturer's recommendations. The mixed sample stream passed through a $\mathrm{Cr}_{2} \mathrm{O}_{3}$ catalyst for conversion of NO to $\mathrm{NO}_{2}$ (Levaggi et al. 1974). The $\mathrm{NO}_{2}$ chemiluminescent analyzer was standardized by a two-point calibration approximately hourly.

Frequent standardization in the field was necessary because the LMA-3 was relatively unstable under the changing temperature, humidity, and background contaminant levels found in the field. Varner et al. (Varner et al. 2003) found that intraday variation in standards could be as great as $60 \%$ even after accounting for linear drift between the beginning and the end of a measurement day. We also compared the concentration of the field NO standard periodically with laboratory standards to assure that they did not drift (Veldkamp and Keller 1997).

Signals from the $\mathrm{CO}_{2}$ and $\mathrm{NO}_{2}$ analyzers and the mass flowmeter for the $\mathrm{NO}$ standard gas were recorded on a datalogger (Campbell CR10). Fluxes were calculated from the linear increase of concentration versus time adjusted for the ratio of chamber volume to area and the air density within the chamber.

\subsection{Analysis of $\mathrm{CH}_{4}$ and $\mathrm{N}_{2} \mathrm{O}$}

We made static enclosure measurements for $\mathrm{CH}_{4}$ and $\mathrm{N}_{2} \mathrm{O}$ fluxes using the same bases and vented caps (Keller and Reiners 1994). Four enclosure headspace samples were taken over a 30-min sampling period with 20 -mL nylon syringes. Analysis of grab samples for $\mathrm{CH}_{4}$ and $\mathrm{N}_{2} \mathrm{O}$ were completed within $36 \mathrm{~h}$ by FID and ECD gas chromatography. Gas concentrations were calculated by comparing peak areas for samples to those for commercially prepared standards (ScottMarin) that had been calibrated against the LBA-ECO (a component of the LargeScale Biosphere-Atmosphere Experiment in Amazonia) standards prepared by the National Oceanic and Atmospheric Administration/Climate Monitoring and Diagnostic Laboratory (NOAA/CMDL). Fluxes were calculated similarly to those for $\mathrm{CO}_{2}$ and $\mathrm{NO}$. 
Earth Interactions - Volume 9 (2005) - Paper No. 23 - Page 8

\subsection{Determination of soil WFPS}

Soil samples were taken to $10-\mathrm{cm}$ depth in each chamber location on each date for determination of soil moisture (oven dried at $105^{\circ} \mathrm{C}$ ). Soil moisture was expressed as WFPS using soil bulk densities of 1.25 and 1.02 for Ultisol and Oxisol soils, respectively, at the undisturbed forest sites (Silver et al. 2000). Bulk densities for the logged sites were measured as described below. We recorded air and soil $(2-\mathrm{cm}$ depth) temperature using thermistor probes to accompany each soil enclosure measurement. Precipitation was measured daily using a manual rain gauge in an open field approximately $3-7 \mathrm{~km}$ from the various study areas.

\subsection{Ground damage and calculation of excess trace gas fluxes}

The full 100-ha management block logged in 1999 was mapped on the ground using methods described by Pereira et al. (Pereira et al. 2002). Location and dimensions were measured for all roads, decks, and skid trails. We calculated the proportion of the soil area affected by mechanical disturbance using a geographic information system. We only measured logging damage for the Oxisol site logged in 1999. We applied these damage estimates for the Ultisol site in order to estimate excess flux. The approximate area covered by gaps was estimated by comparison to similarly logged sites in eastern Para assuming a gap radius of $20 \mathrm{~m}$ per harvested tree characteristic of RIL and a harvest density of 3.5 trees ha $^{-1}$ (Asner et al. 2004).

To quantify the effect of logging on trace gas fluxes, we calculated an excess flux $\left(\Delta f_{i}=f_{i}-f_{\text {background }}\right)$ that could be attributed to logging for a specific sampling stratum by subtracting the forest background $\left(f_{\text {background }}\right)$ values from the flux for that stratum $\left(f_{i}\right)$. We used data from the forest matrix within the logging sites or the undisturbed forest for background fluxes. As noted below, the forest matrix values generally were statistically indistinguishable from the nearby undisturbed forest sites. The integrated change $(\Delta F)$ in flux that can be attributed to logging was calculated as

$$
\Delta F=\Sigma\left(A_{i} / A_{T}\right) \Delta f_{i},
$$

where $A_{i}$ is the area for a given sampling stratum and $A_{T}$ is the total area subject to the constraint that $\Sigma A_{i}=A_{T}$.

Errors in the calculation $\Delta F$ depend upon both errors in the area determinations and in the errors in flux measurement. We have no estimate of error for the area measurements so we have made an error estimate for $\Delta F$ based only on the error in excess flux $\left(E_{\Delta f i}\right)$. This error depends on the sampling error of the independent components of $\Delta f_{i}$ :

$$
E_{\Delta f i}=\left(E_{f i}^{2}+E_{f \text { background }}^{2}\right)^{0.5}
$$

Because of the large dispersion in flux measurements, we expect this error to dominate over any error in area estimation. We estimate the error on the excess flux as

$$
E_{\Delta F}=\left\{\Sigma\left[\left(A_{i} / A_{T}\right) E_{\Delta f i}\right]^{2}\right\}^{0.5} .
$$

A notable feature of ground damage is soil compaction caused by heavy machinery. We quantified soil compaction by measurement of bulk density for the 0-10- 
Earth Interactions - Volume 9 (2005) - Paper No. 23 • Page 9

$\mathrm{cm}$ layer in all four logging strata in blocks logged in 1999 and 2000 using $300-\mathrm{cm}^{3}$ stainless steel rings to remove intact cores (Blake and Hartge 1986). Eight undisturbed cores were removed from random locations for each sampling stratum in each logging block.

\subsection{Statistical analysis}

Annual average fluxes were computed as the averages of wet- (January to June) and dry-season (July to December) fluxes in order to avoid bias resulting from unequal numbers of samples in each season. The error for the annual flux was propagated from the standard error of the seasonal fluxes $\left(\mathrm{SE}_{\mathrm{wet}}\right.$ and $\left.\mathrm{SE}_{\mathrm{dry}}\right)$ by addition in quadrature with adjustment for $n=2$ in the average (Bevington 1969, p. 60):

$$
\text { Annual error }=0.5 *\left(\mathrm{SE}_{\mathrm{wet}}^{2}+\mathrm{SE}_{\mathrm{dry}}^{2}\right)^{0.5} \text {. }
$$

We compared daily mean fluxes of trace gases, soil moisture, soil temperature, and air temperature for both undisturbed forest using a two-way analysis of variance (ANOVA) with factors for soil type and season as well as a soil by season interaction term. For logged sites, we employed a two-way ANOVA to test for effects of season and damage stratum. In both cases, the replicates are individual sampling dates; chambers' locations were chosen randomly for each date. We applied a $\log$-transformation to $\mathrm{CH}_{4}$ and $\mathrm{N}_{2} \mathrm{O}$ flux data at logged sites in order to homogenize variances for the ANOVA model. It was necessary to add a small positive value to $\mathrm{CH}_{4}$ fluxes prior to log-transformation for ANOVA to avoid transformation of negative values (soil consumption of $\mathrm{CH}_{4}$ ). For soil effects or logging stratum effects within a focal site, the samples may be considered pseudoreplicates (Hurlbert 1984) and we caution that conclusions based upon the statistical tests should not be extended beyond the narrow range of the study sites. We also used ANOVA to test for differences in bulk density for the various damage strata in logged blocks.

\section{Results}

\subsection{Soil moisture and trace gas fluxes in undisturbed forest}

Although our definition of rainy and dry seasons was somewhat arbitrary, the wet periods of January through June received 1783 and $1738 \mathrm{~mm}$ of rain for 2000 and 2001, respectively, compared to the dry periods that received only 576 and 188 $\mathrm{mm}$. On undisturbed forest sites, soil moisture content varied significantly (ANOVA, $p<0.0001$ ) by season and by soil type (Figure $2 \mathrm{e}$ ). Soil moisture was substantially greater when measured during the wet season (January-June) than during the dry season (July-December). Over $2 \mathrm{yr}$ of sampling, wet-season WFPS averaged ( \pm standard error) $48.3 \%( \pm 2.0)$ and $37.8 \%( \pm 3.0)$ for the clay Oxisol and sandy loam Ultisol, respectively, in the top $10 \mathrm{~cm}$. In the dry season the Oxisol and Ultisol soil WFPS fell to an average ( \pm standard error) of $33.1 \%( \pm 3.0)$ and $23.0 \%$ $( \pm 2.6)$ (Figure 2e). Soil temperature at 2-cm depth (not shown) was significantly different by season (ANOVA, $p<0.001$ ), with average temperatures of $24.7^{\circ}$ and $25.4^{\circ} \mathrm{C}$ in the wet and dry seasons, respectively. There was no significant difference in temperature across soil type. 
Earth Interactions • Volume 9 (2005) - Paper No. 23 • Page 10
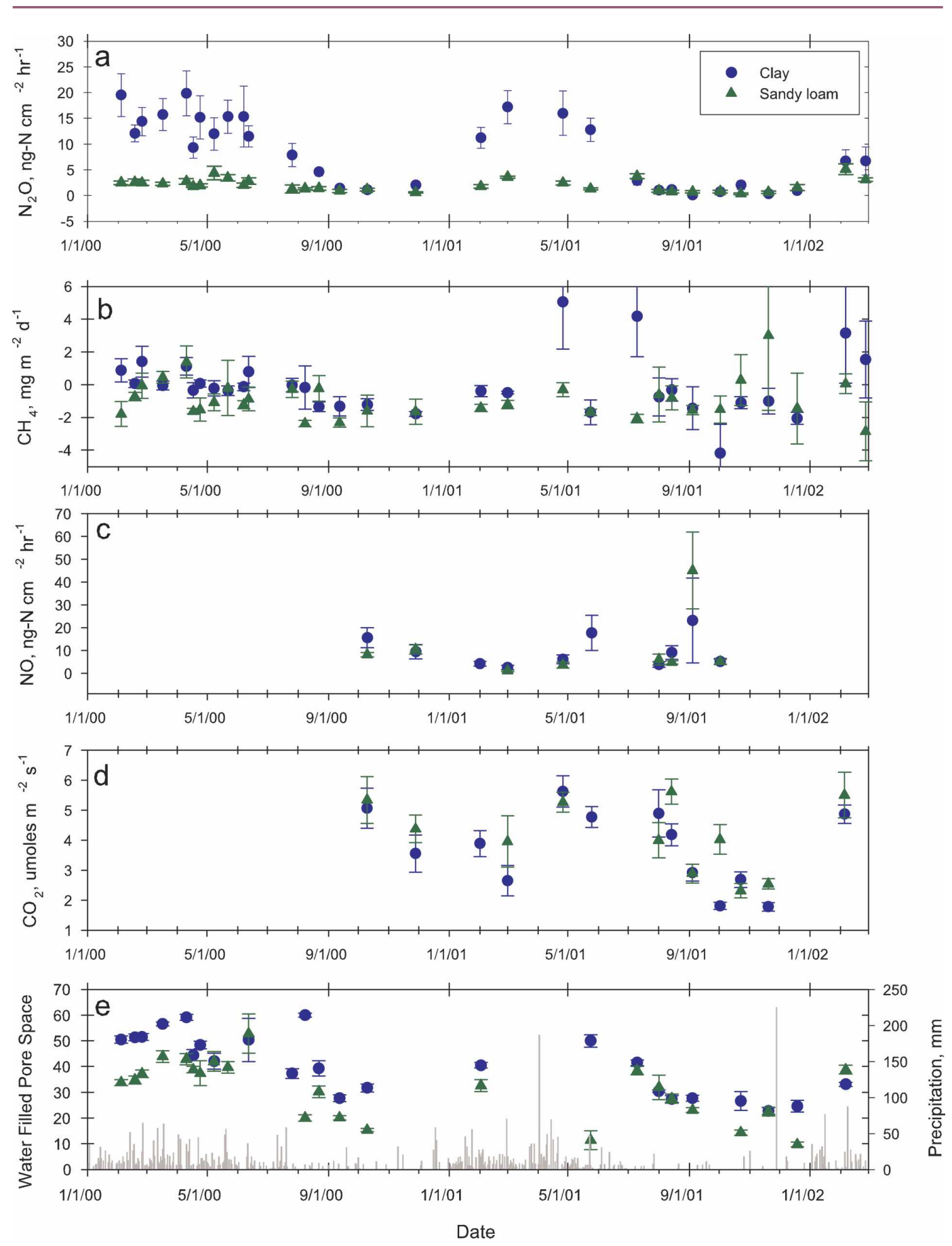

Figure 2. Seasonal patterns of soil-atmosphere trace gas fluxes, soil WFPS, and daily precipitation (gray bars) from undisturbed forest sites on a clay Oxisol and a sandy loam Ultisol in the Tapajos National Forest from 4 Feb 2000 through 26 Feb 2002. Error bars represent standard errors of the mean for individual sampling dates. 
Earth Interactions - Volume 9 (2005) • Paper No. 23 • Page 11
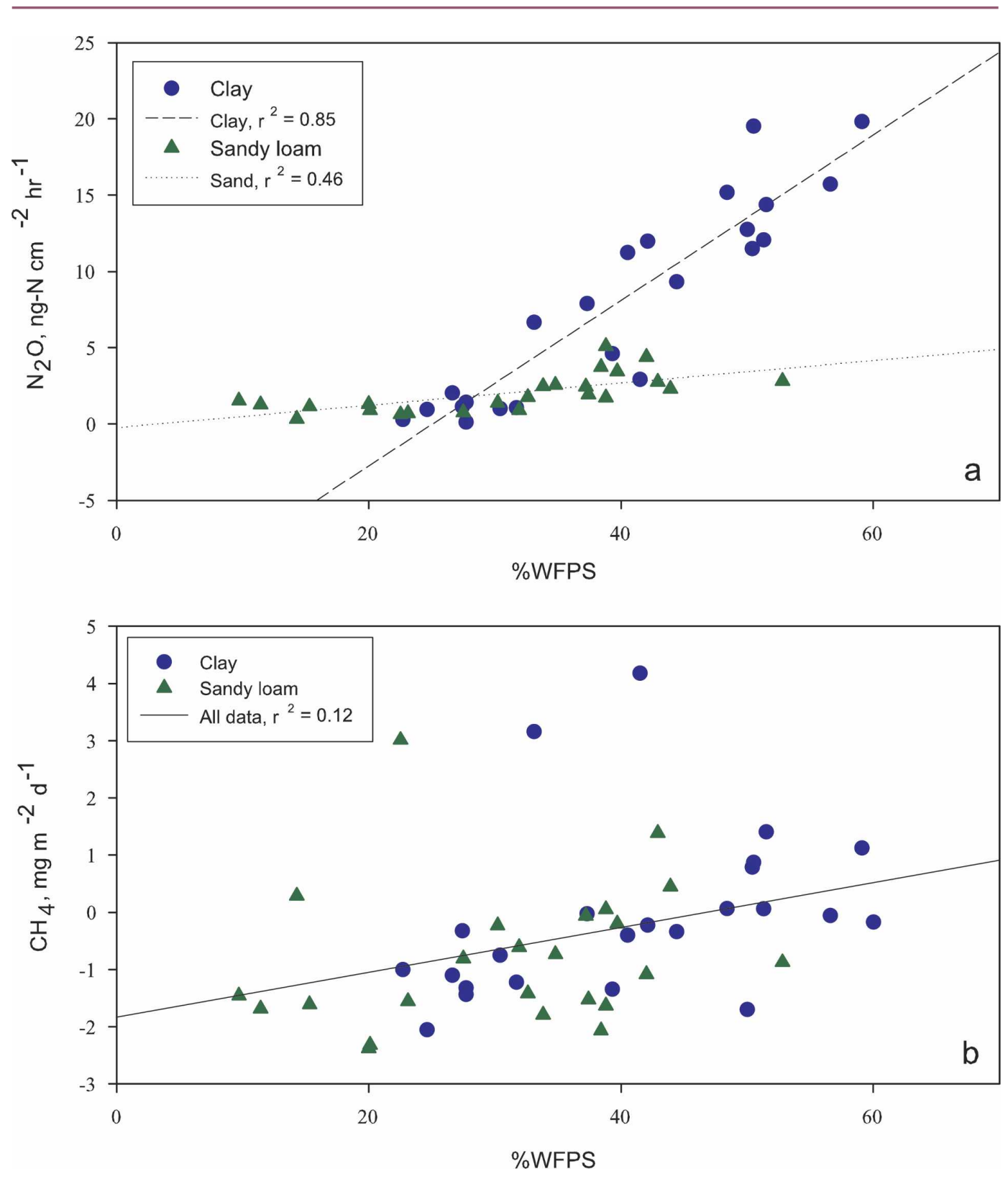

Figure 3. (a) $\mathrm{N}_{2} \mathrm{O}$ and (b) $\mathrm{CH}_{4}$ fluxes vs soil WFPS from clay Oxisol (circles) and sandy loam Ultisol (triangles) soils from undisturbed sites in the Tapajos National Forest.

In the undisturbed forest $\mathrm{N}_{2} \mathrm{O}$ flux responded significantly to WFPS (Figure 3a). For the clay Oxisol, the seasonal pattern of $\mathrm{N}_{2} \mathrm{O}$ flux was repeated over $2 \mathrm{yr}$ with clear peaks during the wet season when fluxes averaged $12.9 \mathrm{ng} \mathrm{N} \mathrm{cm}^{-2} \mathrm{~h}^{-1}$ and troughs in the dry season when fluxes averaged $1.9 \mathrm{ng} \mathrm{N} \mathrm{cm}^{-2} \mathrm{~h}^{-1}$ (Figure 2a; Table 1). The seasonal pattern on the sandy loam Ultisol was similar although muted with average $\mathrm{N}_{2} \mathrm{O}$ fluxes for wet and dry seasons of 2.1 and $1.1 \mathrm{ng} \mathrm{N} \mathrm{cm}^{-2}$ 
Earth Interactions - Volume 9 (2005) - Paper No. 23 • Page 12

Table 1. Seasonal and annual estimates of average trace gas fluxes (standard error $(\mathrm{SE})$ ) in undisturbed forest sites for (a) clay Oxisol and (b) sandy loam Ultisol. We only sampled $\mathrm{CO}_{2}$ and $\mathrm{NO}$ fluxes in the dry season of 2000 so no annual estimate is given for those gases in that year. Annual fluxes are estimated as the average of wet- and dry-season fluxes. Error estimates for annual fluxes are propagated according to Equation (4). Sampling dates for 2002 are not included in the annual averages.

\begin{tabular}{|c|c|c|c|c|c|}
\hline & & $\mathrm{N}_{2} \mathrm{O}(\mathrm{SE})$ & NO (SE) & $\mathrm{CH}_{4}(\mathrm{SE})$ & $\mathrm{CO}_{2}(\mathrm{SE})$ \\
\hline Year & Season & $\mathrm{ng} \mathrm{N} \mathrm{cm}{ }^{-2} \mathrm{~h}^{-1}$ & $\mathrm{ng} \mathrm{N} \mathrm{cm}^{-2} \mathrm{~h}^{-1}$ & $\overline{\mathrm{mg} \mathrm{CH}} \mathrm{m}^{-2} \mathrm{day}^{-1}$ & $\mu \mathrm{mol} \mathrm{\textrm {m } ^ { - 2 } \mathrm { s } ^ { - 1 }}$ \\
\hline \multicolumn{6}{|l|}{ Clay Oxisol } \\
\hline 2000 & Wet & $13.0(0.9)$ & na & $0.3(0.2)$ & na \\
\hline 2000 & Dry & $2.7(1.0)$ & $12.5(3.1)$ & $-1.0(0.3)$ & $4.3(0.8)$ \\
\hline 2000 & Annual & $7.9(0.7)$ & na & $-0.3(0.2)$ & na \\
\hline 2001 & Wet & $12.8(1.2)$ & $7.7(3.4)$ & $0.6(1.5)$ & $4.2(0.6)$ \\
\hline 2001 & Dry & $1.2(0.3)$ & $10.4(4.4)$ & $-0.8(0.8)$ & $3.0(0.5)$ \\
\hline 2001 & Annual & $7.0(0.6)$ & $9.0(2.8)$ & $-0.1(0.9)$ & $3.6(0.4)$ \\
\hline \multicolumn{6}{|c|}{ Sandy loam Ultisol } \\
\hline 2000 & Wet & $2.3(0.2)$ & na & $-0.7(0.3)$ & na \\
\hline 2000 & Dry & $1.0(0.1)$ & $9.4(1.1)$ & $-1.4(0.4)$ & $4.9(0.5)$ \\
\hline 2000 & Annual & $1.7(0.1)$ & na & $-1.0(0.2)$ & na \\
\hline 2001 & Wet & $2.0(0.4)$ & $2.3(1.3)$ & $-1.2(0.3)$ & $6.2(2.2)$ \\
\hline 2001 & Dry & $1.2(0.4)$ & $15.3(9.9)$ & $-0.6(0.6)$ & $3.6(0.5)$ \\
\hline 2001 & Annual & $1.6(0.3)$ & $8.8(5.0)$ & $-0.9(0.3)$ & $4.9(1.1)$ \\
\hline
\end{tabular}

$\mathrm{h}^{-1}$, respectively (Table 1). The $\mathrm{N}_{2} \mathrm{O}$ flux was significantly different (ANOVA, $p$ $<0.0001$ ) among season and soil type although there was also a significant season by soil interaction. This interaction is evident by inspection of Figure $2 \mathrm{a} ; \mathrm{N}_{2} \mathrm{O}$ fluxes are greater on clay versus sand during the wet season while during the dry season they fall to similarly low levels.

Sampling for NO flux in the undisturbed forest was limited by instrument availability prior to October 2000 and by problems of instrument reliability thereafter. We report soil-atmosphere NO fluxes for only 10 and 8 sampling dates on the Oxisol and Ultisol, respectively (Figure 2c). We found no significant effect of either soil type or season on NO flux. The overall average NO flux for 2001 was $8.9 \mathrm{ng} \mathrm{N} \mathrm{cm}{ }^{-2} \mathrm{~h}^{-1}$ (Table 1).

Soil-atmosphere exchange of $\mathrm{CH}_{4}$ included both net negative fluxes (soil consumption of atmospheric methane) and net positive fluxes (soil emission of methane) in both the wet and dry seasons regardless of soil type. There was a trend of decreasing $\mathrm{CH}_{4}$ fluxes with decreasing WFPS, but the correlation was weak and insignificant (Figure $3 b$ ) regardless of soil type. Both seasonal and soil effects were significant in the analysis of variance $(p<0.05)$ and there was no significant interaction. On the clay Oxisol, in the wet season methane production dominated consumption, and the average $\mathrm{CH}_{4}$ flux combining 2000 and 2001 was $0.5 \mathrm{mg} \mathrm{CH}_{4}$ $\mathrm{m}^{-2}$ day $^{-1}$ (Table 1). In contrast, in the dry season on the clay Oxisol, consumption dominated and the average flux was $-0.9 \mathrm{mg} \mathrm{CH}_{4} \mathrm{~m}^{-2}$ day $^{-1}$ over those two years. Methane consumption always dominated over production on the sandy loam Ultisol. Compared with the Oxisol, methane flux was significantly more negative on 
Earth Interactions - Volume 9 (2005) - Paper No. 23 • Page 13

the sandy loam Ultisol with wet- and dry-season averages of -0.9 and $-1.0 \mathrm{mg}$ $\mathrm{CH}_{4} \mathrm{~m}^{-2}$ day $^{-1}$ combining 2000 and 2001(Table 1).

Soil-atmosphere $\mathrm{CO}_{2}$ flux averaged $4.1( \pm 0.3) \mu \mathrm{mol} \mathrm{m} \mathrm{m}^{-2} \mathrm{~s}^{-1}$ for all measurements (unweighted) in undisturbed forest (Table 1). We found no significant effect of either soil type or season on $\mathrm{CO}_{2}$ flux. Although not significant, there is a noticeable trend of diminishing $\mathrm{CO}_{2}$ flux and diminishing soil moisture during the dry season (July through December) of 2001 (Figures 2d and 2e).

\subsection{Effects of moisture and temperature on trace gas fluxes}

In the undisturbed forest, soil WFPS had a significant influence on $\mathrm{N}_{2} \mathrm{O}$ flux (Figure 3). There was no significant correlation between $\mathrm{CO}_{2}, \mathrm{CH}_{4}$, or $\mathrm{NO}$ and soil WFPS. Daily average soil moisture was significantly $\left(r^{2}=0.37, p<0.001\right)$ inversely correlated with daily average soil temperature (not shown) although the daily range of temperature was very limited, $23.3^{\circ}$ to $27.6^{\circ} \mathrm{C}$. The inverse correlation of moisture and temperature results in a weak, although significant, negative correlation of $\mathrm{N}_{2} \mathrm{O}$ flux with soil temperature $\left(r^{2}=0.15, p<0.01\right)$.

\subsection{Trace gas fluxes in logged forest}

The seasonal patterns of $\mathrm{N}_{2} \mathrm{O}$ and $\mathrm{CH}_{4}$ flux following logging are shown in Figure 4 for the focal site on clay Oxisol sampled in 2000. For $\mathrm{N}_{2} \mathrm{O}$ the pattern of high fluxes in the wet season followed by low fluxes in the dry season (Figure 4a) resembled the pattern for a similar undisturbed forest site on clay Oxisol (Figure 2a). Skid trails, gaps, and forest matrix all followed this pattern. In contrast, $\mathrm{N}_{2} \mathrm{O}$ fluxes for the logging decks showed an inverted pattern with the greatest soil to atmosphere fluxes during the dry season. Annual average $\mathrm{N}_{2} \mathrm{O}$ fluxes ranged from 7.5 to $14.7 \mathrm{ng} \mathrm{N} \mathrm{cm}^{-2} \mathrm{~h}^{-1}$ across the various strata (damage classes) (Table 2). Analysis of variance on log-transformed $\mathrm{N}_{2} \mathrm{O}$ flux data showed no significant difference among logging strata. There was a significant $(p<0.001)$ season by stratum interaction because of the inverted seasonal trends for $\mathrm{N}_{2} \mathrm{O}$ fluxes (greater in the dry season) from the decks discussed below.

For $\mathrm{CH}_{4}$ at the focal logging site in 2000, gap and forest matrix strata had annual fluxes ( -0.7 to $4.4 \mathrm{mg} \mathrm{CH}_{4} \mathrm{~m}^{-2}$ day $^{-1}$ ) similar to or slightly greater than the forest matrix (Table 2). Logging had a significant effect on $\mathrm{CH}_{4}$ flux (ANOVA, $p<0.01$ ) because emissions of $\mathrm{CH}_{4}$ were extremely high for the heavily compacted logging decks where water frequently ponded over portions of the surface during the wet season. Dry-season emissions on log decks were dominated by a single sampling date (1 August 2000). Excluding this date, the dry-season average ( \pm standard error) would be only $0.6( \pm 0.2) \mathrm{mg} \mathrm{CH}_{4} \mathrm{~m}^{-2}$ day $^{-1}$.

We collected data for soil-atmosphere fluxes of $\mathrm{NO}$ and $\mathrm{CO}_{2}$ for our focal site on only two dates in the dry season of 2000 (Table 2). Dry-season NO flux from $\log$ decks was significantly greater than NO fluxes from other logging strata (ANOVA, $p<0.05$ ). There were no significant differences among $\mathrm{CO}_{2}$ fluxes for the different logging strata.

Additional fluxes measured in other logged forests on clay Oxisol during 2000 confirm the patterns found at our focal site (Table 3). Differences in soilatmosphere fluxes of $\mathrm{N}_{2} \mathrm{O}$ and $\mathrm{CO}_{2}$ across logging damage strata were minor. 
Earth Interactions - Volume 9 (2005) - Paper No. 23 • Page 14
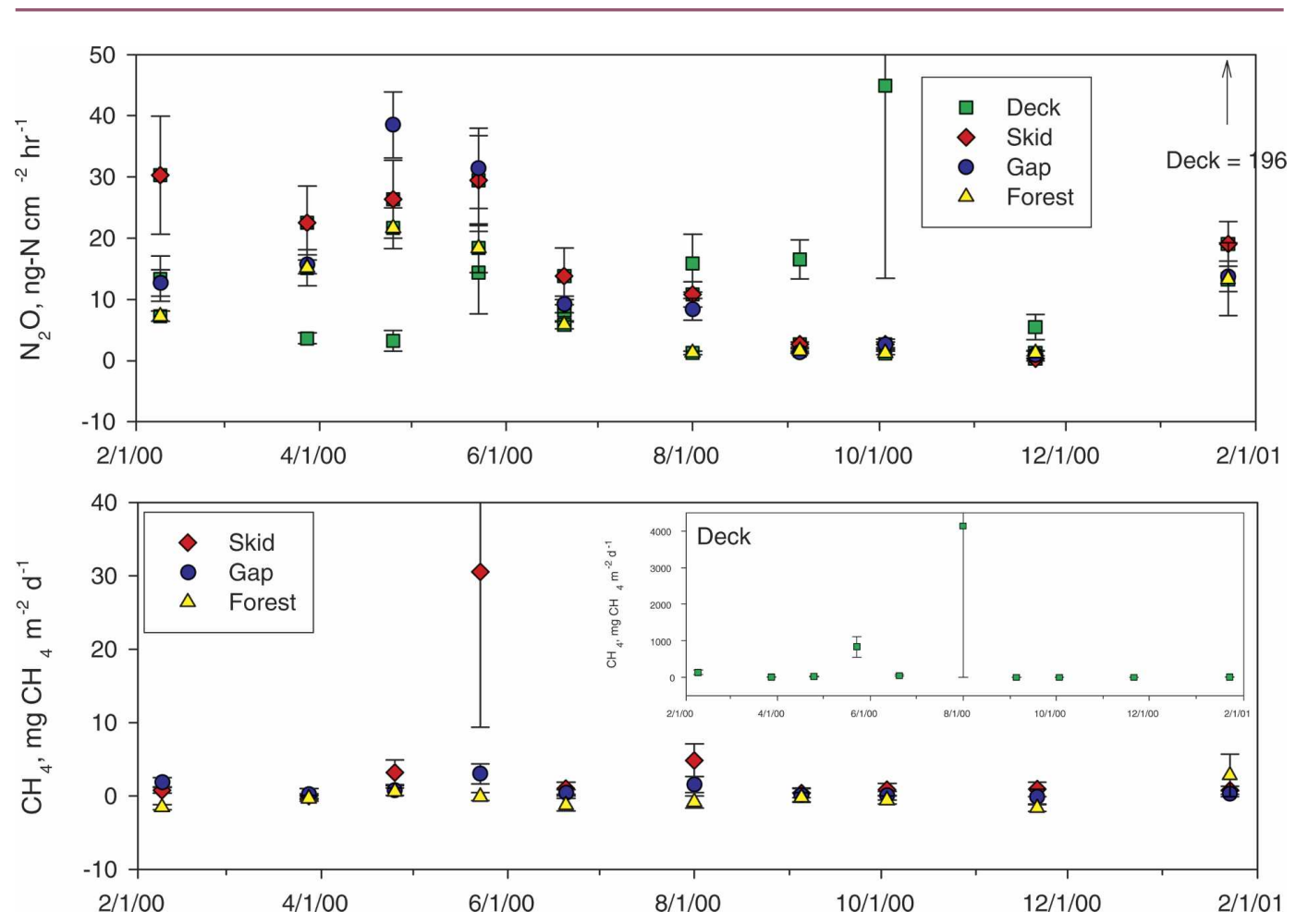

Figure 4. Seasonal patterns of soil-atmosphere fluxes of $\mathrm{N}_{2} \mathrm{O}$ and $\mathrm{CH}_{4}$ in the focal study site logged in 1999 and sampled in 2000. Data are shown from four strata indicating decreasing levels of damage: decks (open squares), skids (filled diamonds), gaps (filled circles), and forest matrix (filled triangles). Error bars represent standard errors of the mean for individual sampling dates.

There was a tendency toward greater NO fluxes from skids and decks, but sampling was unbalanced. As was the case for our focal site in 2000, log decks had greatly elevated $\mathrm{CH}_{4}$ emissions during the wet season. Skid trails had somewhat elevated $\mathrm{CH}_{4}$ emissions compared to gaps and the background forest matrix.

Soil-atmosphere fluxes of $\mathrm{CH}_{4}, \mathrm{CO}_{2}, \mathrm{~N}_{2} \mathrm{O}$, and $\mathrm{NO}$ from Ultisol sites logged in

Table 2. Seasonal and annual estimates of average trace gas fluxes (standard error) in the focal logged forest sites (deck 3) for clay Oxisol logged in 1999 and sampled in 2000. Annual fluxes are estimated as the average of wet- and dry-season fluxes. Error estimates for annual fluxes are propagated according to Equation (4).

\begin{tabular}{lrrrrrrr}
\hline & \multicolumn{3}{c}{$\mathrm{N}_{2} 0\left(\mathrm{ng} \mathrm{N} \mathrm{cm}^{-2} \mathrm{~h}^{-1}\right)$} & & \multicolumn{3}{c}{$\mathrm{CH}_{4}\left(\mathrm{mg} \mathrm{CH}_{4} \mathrm{~m}^{-2}\right.$ day $\left.^{-1}\right)$} \\
\cline { 2 - 3 } \cline { 7 - 8 } & \multicolumn{1}{c}{ Wet } & \multicolumn{1}{c}{ Dry } & Annual & & Wet & \multicolumn{1}{c}{ Dry } & Annual \\
\hline Forest & $13.7(3.1)$ & $1.3(0.1)$ & $7.5(1.6)$ & & $-0.5(0.4)$ & $-0.8(0.3)$ & $-0.7(0.2)$ \\
Gap & $21.5(5.7)$ & $3.3(1.7)$ & $12.4(3.0)$ & & $1.3(0.5)$ & $0.4(0.4)$ & $0.8(0.3)$ \\
Skid & $24.5(3.0)$ & $4.1(2.3)$ & $14.3(1.9)$ & & $7.1(5.9)$ & $1.8(1.0)$ & $4.4(3.0)$ \\
Deck & $8.6(2.3)$ & $18.2(7.0)$ & $13.3(3.7)$ & & $211(159)$ & $852(823)$ & $531(419)$ \\
\hline
\end{tabular}


Earth Interactions • Volume 9 (2005) • Paper No. 23 • Page 15

September 2000 and measured from February 2001 through January 2002 are displayed in Table 4. Similar to observations made during 2000, the most salient result is the large increase of $\mathrm{CH}_{4}$ emission from log decks (annual average emission of $98 \mathrm{mg} \mathrm{CH}_{4} \mathrm{~m}^{-2} \mathrm{day}^{-1}$ ) compared to other damage strata (0.0 to $2.4 \mathrm{mg}$ $\mathrm{CH}_{4} \mathrm{~m}^{-2}$ day $\left.^{-1}\right)$. Analysis of variance of log-transformed $\mathrm{CH}_{4}$ fluxes showed a significant effect of stratum, season, as well as a season by stratum interaction ( $p$ $<0.001)$. The interaction results from very high emissions of $\mathrm{CH}_{4}$ from ponded decks during the wet season compared to low emissions during the dry season. Other strata have a muted seasonal signal by comparison (Table 4). In contrast to $\mathrm{CH}_{4}$, logging had no significant effect on soil-atmosphere exchange of $\mathrm{CO}_{2}$.

The behavior of soil-atmosphere $\mathrm{N}_{2} \mathrm{O}$ and $\mathrm{NO}$ fluxes from the logged Ultisol sites were inverted both with respect to season and with respect to logging damage. Greatest $\mathrm{N}_{2} \mathrm{O}$ fluxes were observed during the wet season and in the more compacted soils of log decks and skid trails (Table 4). The greatest NO fluxes were found during the dry season from the forest matrix and logging gap soils that did not suffer compaction. In both cases analysis of variance on log-transformed data showed a significant effect of season and logging stratum $\left(\mathrm{N}_{2} \mathrm{O}\right.$ and $\mathrm{NO}, p<$ $0.001)$.

\subsection{Comparison of fluxes in undisturbed forest versus the background matrix in logged sites}

We compared undisturbed forest fluxes of $\mathrm{N}_{2} \mathrm{O}$ and $\mathrm{CH}_{4}$ for the clay Oxisol background forest site and the focal logging site on the same soil type during 2000 using ANOVA. Average daily fluxes were taken as replicates. Both $\mathrm{N}_{2} \mathrm{O}$ and $\mathrm{CH}_{4}$ fluxes were significantly greater in the wet season versus the dry season. However, there was no significant difference by site. Undisturbed forest and the forest matrix in the logged site have similar fluxes. We only sampled $\mathrm{NO}$ and $\mathrm{CO}_{2}$ in the dry season of 2000. We found no significant differences in fluxes for these gases between the undisturbed forest and matrix forest in logged sites.

We performed the same analysis on the Ultisol sites measured in 2001 with a similar outcome for all gases but $\mathrm{N}_{2} \mathrm{O}$. In the case of $\mathrm{N}_{2} \mathrm{O}$ flux, the ANOVA on log-transformed data shows a significant $(p<0.001)$ effect of season as expected but unexpectedly a significantly greater $\mathrm{N}_{2} \mathrm{O}$ flux from the forest matrix within the logging site than for the background forest site. In the case of $\mathrm{CH}_{4}$, neither site nor season had a significant effect. For log-transformed values of NO flux, there was a significant $(p<0.05)$ seasonal effect with greater fluxes in the dry season but no effect of site. The $\mathrm{CO}_{2}$ fluxes were significantly greater $(p<0.05)$ in the wet season, but again there was no effect of site. Overall, with the exception of $\mathrm{N}_{2} \mathrm{O}$ on the Ultisols in 2001 we could find no significant effect of site on trace gas flux when comparing the background forest with the relatively undisturbed forest matrix within the logging sites.

\subsection{Ground damage resulting from logging}

Approximately 10 ha (10\%) of the ground area in block 3 logged in 1999 suffered mechanical disturbance and compaction due to the passage of skidders, loaders, crawler tractors, and trucks. About $1.3 \%$ of the area was covered by roads, $7.7 \%$ 
Earth Interactions - Volume 9 (2005) • Paper No. 23 • Page 16
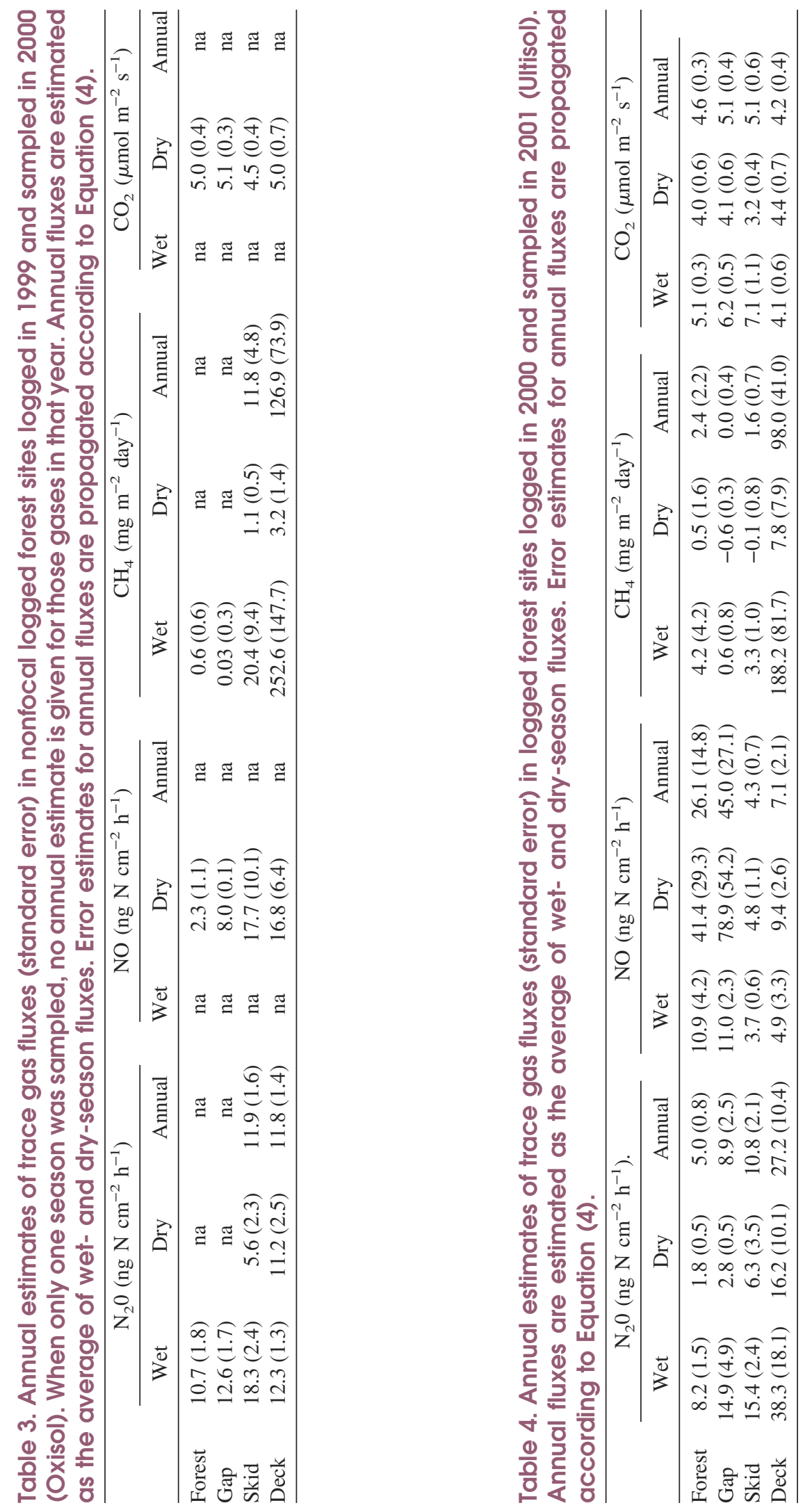
Earth Interactions • Volume 9 (2005) • Paper No. 23 • Page 17

Table 5. Average ( \pm SE) bulk density for surface soil $(0-10 \mathrm{~cm})$ in management blocks 3 (logged in 1999) and 9 (logged in 2000) in four disturbance classes ( $n=8$ per class).

\begin{tabular}{cccccc}
\hline & & Deck & Skid trail & Clearing & Forest \\
\cline { 3 - 6 } Block & Soil & \multicolumn{4}{c}{$\mathrm{Mg} \mathrm{m}^{-3}$} \\
\hline 3 & Oxisol & $1.28(0.05)$ & $1.09(0.07)$ & $1.07(0.06)$ & $1.04(0.04)$ \\
9 & Ultisol & $1.26(0.07)$ & $1.04(0.05)$ & $1.00(0.05)$ & $1.02(0.04)$ \\
\hline
\end{tabular}

by skids, and $0.8 \%$ by decks. The majority $(78 \%)$ of the mechanical disturbance was caused by skidding along the dendritic pattern of planned trails (Figure 1). Mechanical disturbance led to significantly increased bulk density (ANOVA, $p<$ 0.01 ) especially in the soils on logging decks on both the clay Oxisol and sandy loam Ultisol (Table 5).

\subsection{Excess trace gas fluxes resulting from logging}

The excess soil-atmosphere fluxes resulting from logging are presented in Table 6 . We performed the calculation only when a full year of data was available so we concentrated on the focal site on the Oxisol (Table 2) and the combined sampling on the Ultisol (Table 4). The excess flux was quite sensitive to our assumption of background. We calculated excess fluxes using either the undisturbed forest fluxes (Table 1) for the appropriate year and soil type or the forest matrix within the logging site as background values ( $\left.f_{\text {background }}\right)$. Where the undisturbed forest is considered the background, we also considered the forest matrix within the logging sites as part of the treatment effect although with only one exception: there was no statistically significant difference between the fluxes from the forest matrix in the logged sites and the fluxes measured in undisturbed forest. For $\mathrm{N}_{2} \mathrm{O}$ flux from the Ultisol site studied in 2001, the forest matrix flux at the logged site was $5.0( \pm 0.8) \mathrm{ng} \mathrm{N} \mathrm{cm}{ }^{-2} \mathrm{~h}^{-1}$. This was significantly greater than the flux in the undisturbed forest, only $1.6( \pm 0.3)$ during the same period. When we used the undisturbed forest for the background value, then the excess flux is $7.9 \mathrm{~kg} \mathrm{~N} \mathrm{~N}_{2} \mathrm{O}$ $\mathrm{ha}^{-1} \mathrm{yr}^{-1}$. However, if we considered the forest matrix within the logging site to be the background then the excess flux diminished to only $3.2 \mathrm{~kg} \mathrm{~N}_{2} \mathrm{O} \mathrm{ha}^{-1} \mathrm{yr}^{-1}$ (Table 6b).

\section{Discussion}

\subsection{Trace gas fluxes in undisturbed forest}

Soil-atmosphere fluxes of $\mathrm{N}_{2} \mathrm{O}$ from the undisturbed forest site on the clay Oxisol, 6.9 and $6.1 \mathrm{~kg} \mathrm{~N} \mathrm{ha}^{-1} \mathrm{yr}^{-1}$ for 2000 and 2001, were among the highest fluxes measured for any lowland old-growth tropical moist forest ecosystem. On the other hand, the fluxes for the sandy loam Ultisol, 1.5 and $1.4 \mathrm{~kg} \mathrm{~N} \mathrm{ha}^{-1} \mathrm{yr}^{-1}$ for 2000 and 2001, fell toward the lower end of values recently compiled by Breuer et al. (Breuer et al. 2000). The $\mathrm{N}_{2} \mathrm{O}$ fluxes from the clay Oxisol were especially high when compared to measured fluxes on similar clay-textured Oxisols in the municipalities of Manaus and Paragominas, Brazil, where annual fluxes ranged from 1.9 to $2.4 \mathrm{~kg} \mathrm{~N} \mathrm{ha}^{-1} \mathrm{yr}^{-1}$ (Luizão et al. 1989; Verchot et al. 1999). The $\mathrm{N}_{2} \mathrm{O}$ 
Earth Interactions • Volume 9 (2005) • Paper No. 23 • Page 18

Table 6a. Average annual fluxes (SE) and calculated excess fluxes (propagated error) as in Equation (3) for the Oxisol site harvested in 1999 and measured in 2000. The $\mathrm{CO}_{2}$ equivalents (shown in boldface) of the excess fluxes were calculated using the 2001 IPCC GWP for the greenhouse gases $\mathrm{N}_{2} \mathrm{O}$ and $\mathrm{CH}_{4}$ (Ramaswamy et al. 2001).

\begin{tabular}{|c|c|c|c|c|c|}
\hline Oxisol & Area $\left(A_{i} / A_{T}\right)$ & $\begin{array}{c}\mathrm{N}_{2} \mathrm{O} \mathrm{kg} \\
\mathrm{N}_{2} \mathrm{O} \mathrm{ha}^{-1} \mathrm{yr}^{-1}\end{array}$ & $\begin{array}{c}\text { NO kg } \\
\text { NO ha }{ }^{-1} \mathrm{yr}^{-1}\end{array}$ & $\begin{array}{c}\mathrm{CH}_{4} \mathrm{~kg} \\
\mathrm{CH}_{4} \mathrm{ha}^{-1} \mathrm{yr}^{-1}\end{array}$ & $\begin{array}{c}\mathrm{CO}_{2} \mathrm{~kg} \\
\mathrm{CO}_{2} \mathrm{ha}^{-1} \mathrm{yr}^{-1}\end{array}$ \\
\hline Background forest & & $10.9(1.0)$ & - & $-1.1(0.7)$ & \\
\hline Forest matrix & 0.475 & $10.4(2.2)$ & - & $-2.6(0.7)$ & - \\
\hline Gap & 0.440 & $17.1(4.1)$ & - & $2.9(1.1)$ & - \\
\hline Skid trail & 0.077 & $19.7(2.6)$ & - & $16.1(11.0)$ & - \\
\hline Deck & 0.008 & $18.4(5.1)$ & - & $1940(1530)$ & - \\
\hline Excess vs matrix & & $3.8(2.2)$ & - & $19.4(12.3)$ & - \\
\hline Excess vs background & & $3.2(2.3)$ & - & $6.8(12.3)$ & - \\
\hline $\mathrm{CO}_{2}$ equivalent vs matrix & & $1110(640)$ & & $450(280)$ & \\
\hline $\mathrm{CO}_{2}$ equivalent vs background & & $950(690)$ & - & $160(280)$ & - \\
\hline
\end{tabular}

emissions from the sandy loam Ultisols were similar to emissions from forests on Ultisol of $1.9 \mathrm{~kg} \mathrm{~N} \mathrm{ha}^{-1} \mathrm{yr}^{-1}$ in the state of Rondonia, Brazil. On both soils, interannual variability was strikingly small considering the episodic nature of $\mathrm{N}_{2} \mathrm{O}$ fluxes (Crill et al. 2000). In comparison, annual estimates for two 1-yr periods of $\mathrm{N}_{2} \mathrm{O}$ fluxes for a wet tropical forest site in Queensland, Australia, using automated chambers measured about four times daily, varied by a factor of 7 (Kiese et al. 2003).

Annual $\mathrm{N}_{2} \mathrm{O}$ fluxes from the undisturbed forest sites were 4 times greater on the clay Oxisol soil compared to the sandy loam Ultisol. This result conforms to the expectations of the hole-in-the-pipe (HIP) model (Firestone and Davidson 1989; Davidson et al. 2000). According to HIP, nitrogen oxide fluxes are controlled at a first level by the rate of nitrogen cycling through the soil system. At a second level in the HIP model, nitrogen oxide fluxes are controlled by soil moisture content that controls the diffusion of oxygen and other gases into the soil. Both levels of control favor greater $\mathrm{N}_{2} \mathrm{O}$ emissions from the clay Oxisol as compared to the sandy loam Ultisol. On the first level, the net nitrification rate, an index of nitrogen cycling, was 3 times higher on the clay Oxisol than on the sandy loam Ultisol (Silver et al. 2000). On the second level, the clay Oxisol had greater WFPS than the sandy loam Ultisol (Figure 3). Additionally, the response of $\mathrm{N}_{2} \mathrm{O}$ fluxes to increases in WFPS

Table 6b. Similar to Table 6a but for the Ultisol site harvested in 2000 and measured in 2001.

\begin{tabular}{|c|c|c|c|c|c|}
\hline Ultisol & $\begin{array}{c}\text { Area } \\
\left(A_{i} / A_{T}\right)\end{array}$ & $\begin{array}{c}\mathrm{N}_{2} \mathrm{O} \mathrm{kg} \\
\mathrm{N}_{2} \mathrm{O} \mathrm{ha}{ }^{-1} \mathrm{yr}^{-1} \\
\end{array}$ & $\begin{array}{c}\text { NO kg } \\
\text { NO ha }{ }^{-1} \mathrm{yr}^{-1}\end{array}$ & $\begin{array}{c}\mathrm{CH}_{4} \mathrm{~kg} \\
\mathrm{CH}_{4} \mathrm{ha}^{-1} \mathrm{yr}^{-1} \\
\end{array}$ & $\begin{array}{c}\mathrm{CO}_{2} \mathrm{~kg} \\
\mathrm{CO}_{2} \mathrm{ha}^{-1} \mathrm{yr}^{-1} \\
\end{array}$ \\
\hline Background forest & & $2.2(1.0)$ & $16.5(9.4)$ & $-3.3(1.1)$ & $67900(15200)$ \\
\hline Forest matrix & 0.475 & $6.9(1.1)$ & $49.1(27.8)$ & $8.8(8.0)$ & $63800(4200)$ \\
\hline Gap & 0.440 & $12.3(3.5)$ & $84.6(50.9)$ & $0.0(1.5)$ & $70700(5500)$ \\
\hline Skid trail & 0.077 & $14.9(2.9)$ & $8.1(1.3)$ & $5.8(2.6)$ & $70700(8300)$ \\
\hline Deck & 0.008 & $37.5(14.4)$ & $13.3(3.9)$ & $357.7(149.7)$ & $58200(5500)$ \\
\hline Excess vs matrix & & $3.2(1.6)$ & $12.2(26.7)$ & $-1.3(4.4)$ & $3540(3340)$ \\
\hline Excess vs background & & $7.9(1.7)$ & $44.7(27.7)$ & $10.8(4.2)$ & $-620(15500)$ \\
\hline $\mathrm{CO}_{2}$ equivalent vs matrix & & $960(490)$ & - & $-30(100)$ & $3540(3340)$ \\
\hline $\mathrm{CO}_{2}$ equivalent vs background & & $2340(500)$ & - & $250(100)$ & $-620(15500)$ \\
\hline
\end{tabular}


Earth Interactions • Volume 9 (2005) - Paper No. 23 • Page 19

was more pronounced. At high moisture contents, denitrification typically dominates tropical forest soil $\mathrm{N}_{2} \mathrm{O}$ production (Parsons et al. 1993). Potential denitrification was 4 times greater on the clay Oxisol than on the sandy loam Ultisol (Silver et al. 2000).

The seasonal pattern of soil-atmosphere fluxes of NO is inverted compared to $\mathrm{N}_{2} \mathrm{O}$. Nitric oxide is easily consumed in soil compared to $\mathrm{N}_{2} \mathrm{O}$ (Galbally and Johansson 1989; Bollmann and Conrad 1998); therefore, NO emission depends much more on gaseous diffusivity in soil. When soils were relatively dry and diffusivity was high, NO emissions were greater than when soils were wet. Emissions from the Oxisol and Ultisol were nearly identical. This observation does not correspond to the first-order nitrogen control in the HIP model possibly because consumption processes dominate over production in the control of emissions.

In comparison to three other Amazon forest sites, soil emissions of NO from our sites at the TNF were very large. We found annual emissions of NO from the sandy loam Ultisol and clay Oxisol of 7.7 and $7.9 \mathrm{~kg} \mathrm{~N} \mathrm{ha}^{-1} \mathrm{yr}^{-1}$ compared to a range of 1.4 to $1.7 \mathrm{~kg} \mathrm{~N} \mathrm{ha}^{-1} \mathrm{yr}^{-1}$ for three other forested sites in the Amazon where seasonal series of measurements are available (Neill et al. 2005). Part of the discrepancy across sites may be methodological. All of our NO flux measurements were calibrated in the field. In contrast, the other measurements in the Amazon, although made using detectors manufactured by the same vendor, were calibrated under laboratory conditions only before and after field measurements. We have found that field calibrations can vary from laboratory calibrations on the same day by as much as $60 \%$ (Varner et al. 2003). This methodological uncertainty probably does not account entirely for the discrepancy between our measurements and those made by others. We note that the higher NO fluxes at our sites compared to others are consistent with similarly higher $\mathrm{N}_{2} \mathrm{O}$ fluxes compared to other sites in the Amazon region.

Soil-atmosphere $\mathrm{CH}_{4}$ fluxes were similar to other sites in the Amazon region. Verchot et al. (Verchot et al. 1999) found annual methane fluxes of $-0.6 \mathrm{mg} \mathrm{CH}_{4}$ $\mathrm{m}^{-2}$ day $^{-1}$ for a forested site in Paragominas on a clay-rich Oxisol and Steudler et al. (Steudler et al. 1996) found annual fluxes averaging from -1.3 to $-2.1 \mathrm{mg} \mathrm{CH}_{4}$ $\mathrm{m}^{-2}$ day $^{-1}$ for an Ultisol at Fazenda Nova Vida in Rondonia, Brazil. The $\mathrm{CH}_{4}$ flux followed seasonal patterns of soil moisture with greatest $\mathrm{CH}_{4}$ consumption during the dry season and moderate production in the wet season similar to other tropical forest sites (Keller and Reiners 1994).

The annual estimates of soil $\mathrm{CO}_{2}$ efflux from the undisturbed forest Oxisol and Ultisol sites for 2001 were about $14( \pm 2)$ and $19( \pm 4) \mathrm{Mg} \mathrm{C} \mathrm{ha}^{-1} \mathrm{yr}^{-1}$. In comparison, we found that soil $\mathrm{CO}_{2}$ efflux summed to about $10 \mathrm{Mg} \mathrm{C} \mathrm{ha}^{-1} \mathrm{yr}^{-1}$ for a site on the same Oxisol about $20 \mathrm{~km}$ away by using an automated system that measured eight chambers about 5 times daily over two years beginning in April 2001 (Saleska et al. 2003). A difference of $4 \mathrm{Mg} \mathrm{C} \mathrm{ha}^{-1} \mathrm{yr}^{-1}$ is quite large in terms of net ecosystem carbon flux. We made our measurements in the daytime imparting a bias toward greater fluxes associated with higher soil temperatures but this effect is slight in the well-shaded tropical forest soils (R. Varner, 2005, personal communication). The limited number of manual $\mathrm{CO}_{2}$ flux measurements at our undisturbed forest Oxisol site and the natural variability of soil-atmosphere flux probably accounts for the observed differences.

Recently, two groups have found that $\mathrm{N}_{2} \mathrm{O}$ and $\mathrm{CO}_{2}$ fluxes correlated in tropical 
Earth Interactions - Volume 9 (2005) - Paper No. 23 • Page 20

forest soils (Breuer et al. 2000; Garcia-Montiel et al. 2002; Garcia-Montiel et al. 2004). In contrast, we found a significant correlation between $\mathrm{N}_{2} \mathrm{O}$ and $\mathrm{CO}_{2}$ fluxes only under very limited conditions, specifically for the sandy loam soil during the dry season. In that case, the slope of the line relating $\mathrm{N}_{2} \mathrm{O}$ and $\mathrm{CO}_{2}$ is far shallower than found by Garcia-Montiel et al. (Garcia-Montiel et al. 2002) (Figure 5). When wet-season data were considered, the correlation between $\mathrm{N}_{2} \mathrm{O}$ and $\mathrm{CO}_{2}$ fluxes disappeared. In tropical forest soils, the $\mathrm{N}_{2} \mathrm{O}$ source has a strong denitrification component (e.g., Parsons et al. 1993; Breuer et al. 2000; Garcia-Montiel et al. 2001). Denitrification is an anaerobic process whereas soil $\mathrm{CO}_{2}$ emissions are promoted by well-aerated moist conditions (Linn and Doran 1984). GarciaMontiel et al. (Garcia-Montiel et al. 2004) have used the correlation between $\mathrm{N}_{2} \mathrm{O}$ and $\mathrm{CO}_{2}$ fluxes for estimation of $\mathrm{N}_{2} \mathrm{O}$ emissions across the Amazon region. This approach ignores denitrification as an important source of $\mathrm{N}_{2} \mathrm{O}$. It fails for our study sites and we believe it is inappropriate for extrapolation across the Amazon region where anaerobic processes exercise a strong control over $\mathrm{N}_{2} \mathrm{O}$ production (Verchot et al. 1999; Garcia-Montiel et al. 2001).

\subsection{The effect of logging on trace gas fluxes}

Passage of heavy machinery over the soil affects about $10 \%$ of the logged area in these RIL managements. Under CL nearly twice as much area would be affected (Pereira et al. 2002). Mechanical disturbance leads to soil compaction. On log decks, the compaction is severe and a $20 \%$ increase in soil bulk density was measured (Table 6). In contrast, there was only moderate compaction on skid trails that was more notable in the clay soils. Soil compaction led to impeded drainage that was especially prominent on the log decks that ponded, at least in part, early during the wet season and did not drain entirely until one to two months after the dry season began. The wet conditions of the decks even in the dry season affects dry-season gas fluxes as we discuss below.

Soil compaction impedes the drainage of water through the soil and results in a reduction of diffusive gas exchange between the soil and the overlying atmosphere. Reduced penetration of oxygen into the soil greatly modifies soil biogeochemical processes. This is illustrated by the shift from a dominance of the oxidative process of $\mathrm{CH}_{4}$ consumption in the undisturbed forest sites to large

production of $\mathrm{CH}_{4}$ on log decks through anaerobic respiration. Production of $\mathrm{CH}_{4}$ from log decks at rates comparable to tropical wetland environments (Crill et al. 1988) was the most notable and consistent change caused by logging.

Shifts in the biogeochemical condition of the soil, especially with regard to oxidation and reduction, were also evident in the seasonal patterns of trace gas flux (Figure 4). Nitrous oxide production and emission are maximized at intermediate levels of soil oxygenation between fully oxidized and fully reduced (Linn and Doran 1984; Keller et al. 1986; Davidson et al. 2000). We found that in the forest matrix, skid trail, and gap logging strata, $\mathrm{N}_{2} \mathrm{O}$ emission peaked during the wet season while on the log decks, $\mathrm{N}_{2} \mathrm{O}$ emission peaked during the dry season. During the wet season log decks were covered with water and the saturated soil was sufficiently reduced to produce large quantities of $\mathrm{CH}_{4}$. Under those strongly reducing conditions, $\mathrm{N}_{2} \mathrm{O}$ would have been consumed by soil denitrifying organisms. Emissions of $\mathrm{NO}$ are favored by drier conditions than emissions of $\mathrm{N}_{2} \mathrm{O}$ 
Earth Interactions - Volume 9 (2005) • Paper No. 23 • Page 21
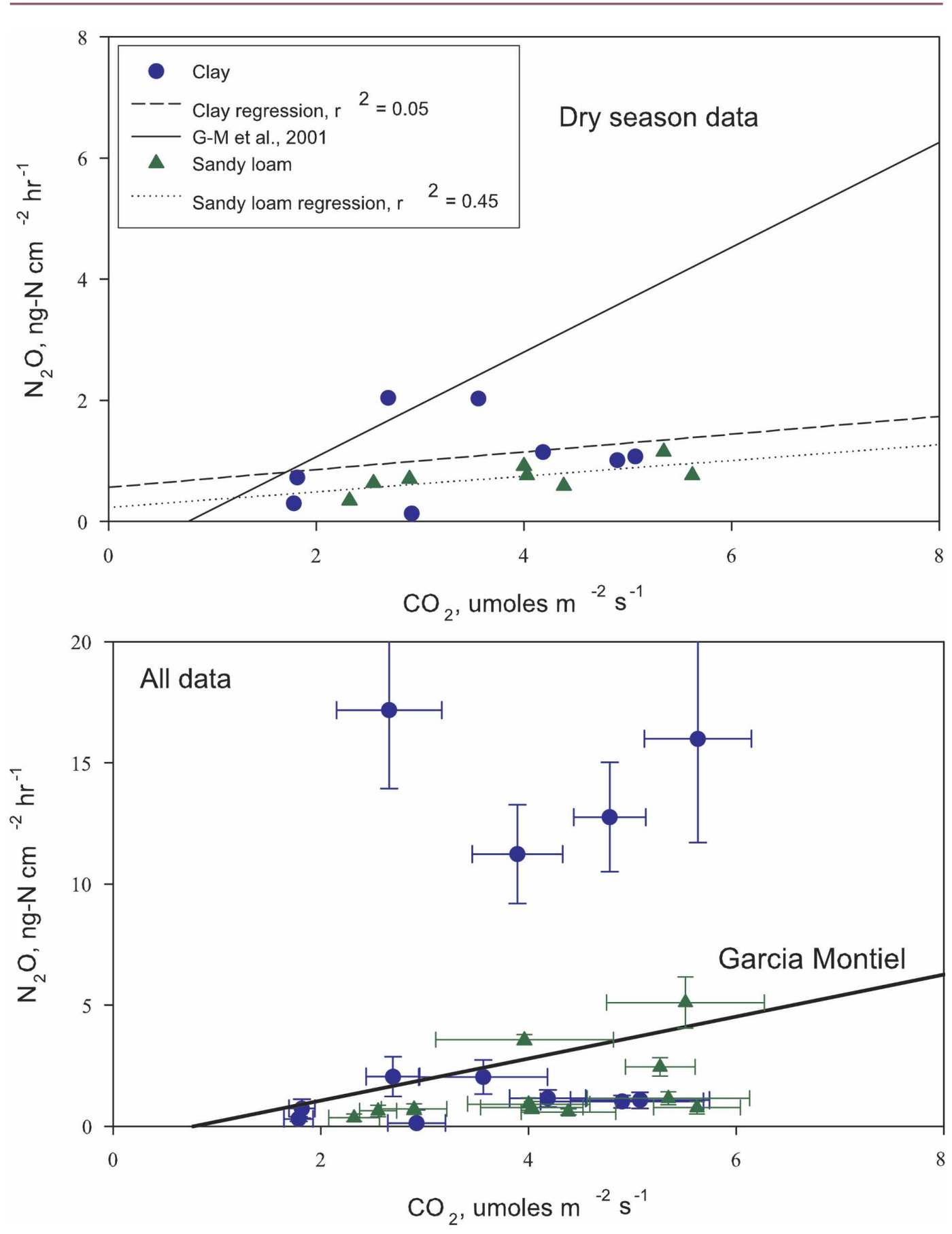

Figure 5. Flux of $\mathrm{N}_{2} \mathrm{O}$ vs $\mathrm{CO}_{2}$ for (top) dry season and (bottom) all data from undisturbed forest sites on both clay Oxisol and sandy loam Ultisol at the Tapajos National Forest. The solid line marks the regression determined for $\mathrm{N}_{2} \mathrm{O}$ vs $\mathrm{CO}_{2}$ for sites in Rondonia (Garcia-Montiel et al. 2002). The dashed and dotted lines show regressions for $\mathrm{N}_{2} \mathrm{O}$ vs $\mathrm{CO}_{2}$ for dry-season data only from the Tapajos National Forest. Error bars represent standard errors of the mean for individual sampling dates. 
Earth Interactions - Volume 9 (2005) - Paper No. 23 • Page 22

(Bollmann and Conrad 1998). In general, the more reducing environments had smaller NO emissions compared to the more oxidizing environments and NO emissions in the dry season exceeded NO emissions during the wet season.

Logging results in a large nearly instantaneous input of organic matter both above- and belowground. Fresh leaves and roots added to the forest floor cause large pulses in nutrient availability in tropical forests (Scatena et al. 1996). Loss of nutrient uptake by roots added to the forest floor causes greater leaching (Brouwer 1996). Nitrate losses from selective harvest in Guyana varied in proportion to the area of soil disturbance surrounding harvested trees. Leaching of nitrate in large harvest gaps was exceptionally high, amounting to $19 \mathrm{~g} \mathrm{~N} \mathrm{~m}^{-2}$ during the first three years following harvest on podsols (Brouwer 1996). Large-scale root disturbance in trenching experiments has also been shown to approximately double the emission of $\mathrm{N}_{2} \mathrm{O}$ during 10 weeks following disturbance (Varner et al. 2003). Root mortality following logging disturbance may contribute to the increased emissions of nitrogen oxides.

\subsection{Possible regional effects of logging on trace gas fluxes}

Logging has become a large-scale land use in the Brazilian Amazon affecting at least $10000 \mathrm{~km}^{2}$ of forest per year (Nepstad et al. 1999) so we evaluate the possibility that regionally significant emissions of trace gases may result from these practices. The effect of logging on soil-atmosphere trace gas flux was often difficult to distinguish statistically because of the high temporal and spatial variability in trace gas fluxes. Nonetheless, even where our experimental design did not reveal significant effects, we used our available measurement to calculate excess trace gas fluxes resulting from logging and we propagated errors for those calculations to indicate the large degree of uncertainty. As noted above, these results can be quite sensitive to the assumption of the background condition.

For the clay Oxisol site, we found that the excess $\mathrm{N}_{2} \mathrm{O}$ flux was about $30 \%$ of the background emission regardless of our assumptions. For the sandy loam Ultisol, the excess flux was of similar magnitude when the forest matrix was considered as background but twice as large when we considered the undisturbed forest site as background. If we consider that logging affects about $1.5 \times 10^{6}$ ha $\mathrm{yr}^{-1}$ in the Brazilian Amazon and we select our largest excess value for $\mathrm{N}_{2} \mathrm{O}$ (7.9 $\mathrm{kg} \mathrm{N}_{2} \mathrm{O} \mathrm{ha}^{-1} \mathrm{yr}^{-1}$ ), then we calculate that the effect of a single year's logging disturbance in Brazil could add up to $7.5 \times 10^{-3} \mathrm{Tg} \mathrm{N}_{2} \mathrm{O} \mathrm{N} \mathrm{yr}{ }^{-1}$ to the troposphere. This effect is at most about $1 \%$ of the estimated emissions of $\mathrm{N}_{2} \mathrm{O}, 0.8 \mathrm{Tg} \mathrm{N}_{2} \mathrm{O} \mathrm{N}$ $\mathrm{yr}^{-1}$ from the Brazilian Amazon region (Melillo et al. 2001). Ground and canopy disturbance at the RIL sites that we studied is about half that of the far more common CL harvest management. Doubling the maximum excess flux that we measured for $\mathrm{N}_{2} \mathrm{O}$ to account for greater ground disturbance in CL would lead to an effect less than $2 \%$ of the estimated annual emissions of $\mathrm{N}_{2} \mathrm{O}$ for the Brazilian Amazon. However, increased fluxes may last more than one year as we will discuss below.

Our data for NO are limited and highly variable. Regardless of the selection of background flux, there was a notable positive enhancement of flux resulting from logging at the Ultisol site. Compared to the long-lived greenhouse gases such as $\mathrm{N}_{2} \mathrm{O}$, it is more difficult to put the increased NO flux into a regional perspective. Increases in regional NO emissions in the Amazon would likely increase the 
Earth Interactions • Volume 9 (2005) • Paper No. 23 • Page 23

regional production of the oxidant and greenhouse gas ozone $\left(\mathrm{O}_{3}\right)($ Keller et al. 1991; Andreae et al. 2002). However, once released from the soil NO oxidizes to form $\mathrm{NO}_{2}$ that is readily consumed in the forest canopy (Rummel et al. 2002). Opening the canopy through logging may increase canopy ventilation and trace gas exchange, but this has not been quantified. Assuming this process led to greater $\mathrm{NO}$ release, we would expect logging to contribute to enhanced $\mathrm{O}_{3}$ production regionally (Keller et al. 1991).

The increase in soil-atmosphere methane emission from log decks was an unambiguous effect of logging. Depending upon our assumptions, logging had anything from a negligible effect on $\mathrm{CH}_{4}$ emissions to a considerable augmentation of emissions. The forest matrix in the logging on the Ultisol had a small net $\mathrm{CH}_{4}$ emission on an annual basis. This net emission is highly uncertain but use of this value as background in Eq. (1) tends to minimize the effect of high fluxes from the log decks on the estimate of excess flux. Using the maximum excess flux of

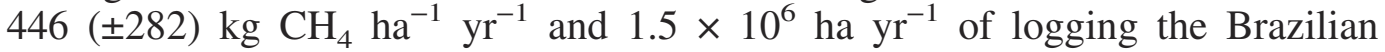
Amazon, we calculate that the effect of a single year's logging disturbance in Brazil could add up to $0.7( \pm 0.4) \mathrm{Tg} \mathrm{CH}_{4} \mathrm{yr}^{-1}$ to the troposphere. Given that the annual production of methane from the full Amazon basin below 500-m elevation is about $29 \mathrm{Tg} \mathrm{CH}_{4}$ (Melack et al. 2004), the potential importance of logging disturbance should not be overlooked. Steudler et al. (Steudler et al. 1996) estimated that the effect of forest to pasture conversion including cattle $\mathrm{CH}_{4}$ emissions accounted for about $2.5 \mathrm{Tg} \mathrm{CH}_{4} \mathrm{yr}^{-1}$ in the Brazilian Amazon in 1990. Logging decks tend to occupy about twice the area under CL management compared to RIL, so our estimates could be as much as a factor of 2 too low.

The importance of logging as an influence on regional trace gas budgets depends on the spatial variability of the response of trace gas emissions to logging. Our studies were limited to one forest with one management approach, although we did study two contrasting soil types that are common in the Amazon region. No single site can be considered representative and we caution that our efforts at extrapolation to the region are mainly to illustrate the possibilities. Definitive conclusions require further studies at other sites.

Our studies of logging effects on trace gas emissions only cover the first year following logging disturbance. Would the perturbations to trace gas emissions occur for longer time periods? If so, then logging would have a more significant regional impact on trace gas budgets. For the nitrogen oxides, both changes in nutrient cycling as well as changes in soil physical properties may have regulated the observed changes in emissions. Excess nitrogen availability following disturbance would probably last at most a few years as found in the case of forest-topasture conversion in the Amazon (Neill et al. 1995). Forest-to-pasture conversion caused increased $\mathrm{N}_{2} \mathrm{O}$ emissions in the Amazon that lasted about three years (Melillo et al. 2001) although the increase of $\mathrm{N}_{2} \mathrm{O}$ flux following disturbance lasted up to a decade in Costa Rica (Keller et al. 1993). If we assume that excess $\mathrm{N}_{2} \mathrm{O}$ fluxes following logging persist for three years at the levels that we observed then logging may augment $\mathrm{N}_{2} \mathrm{O}$ emissions by as much as $5 \%-6 \%$ over current levels on a regional basis.

In the case of $\mathrm{CH}_{4}$, soil compaction is the main driver of excess fluxes. Changes in soil bulk density in skid trails have been shown to last as long as $16 \mathrm{yr}$ by investigators working on the Oxisol at the Tapajos National Forest (McNabb et al. 
Earth Interactions • Volume 9 (2005) • Paper No. 23 • Page 24

1997). Although McNabb et al. (McNabb et al. 1997) did not present data from old logging decks, we also would expect them to remain compact for a long time. However, we have observed that within about three years following logging, log decks are covered by trees and unless these trees are adapted to long periods of root anaerobiosis, it is likely that soil aeration improves with time and that the potential for methane emission on log decks decreases with time. Overall, we would expect compaction-related effects on $\mathrm{CH}_{4}$ flux to diminish with time. Again if we assume a 3-yr time horizon for increased fluxes, it is possible that logging could have an effect on $\mathrm{CH}_{4}$ budgets similar in magnitude $\left(\sim 2 \mathrm{Tg} \mathrm{CH}_{4} \mathrm{yr}^{-1}\right)$ to the net effect of forest-to-pasture conversion.

\subsection{Trace gas emissions and carbon budgets from logging in the Amazon}

To put the trace gas emissions into perspective, we evaluated them compared to $\mathrm{CO}_{2}$ emissions using the concept of global warming potential (GWP). We selected a 100-yr integration time for GWP following the recent recommendations of the Intergovernmental Panel on Climate Change (IPCC; Ramaswamy et al. 2001). In a short-term perspective, a great deal of carbon is effectively committed to release to the atmosphere by logging. We found that even using less destructive RIL techniques at the TNF logging removed the equivalent of $41 \mathrm{Mg} \mathrm{CO}_{2} \mathrm{ha}^{-1}$ in harvested wood and $47 \mathrm{Mg} \mathrm{CO}_{2} \mathrm{ha}^{-1}$ as necromass (Keller et al. 2004a). If we compare the $\mathrm{CO}_{2}$ equivalents of soil emissions of $\mathrm{N}_{2} \mathrm{O}, \mathrm{CH}_{4}$, and $\mathrm{CO}_{2}$ (Table 6) to these instantaneous values, the trace gas effects appear to be small.

There are few carbon budgets for logged tropical forest sites and most consider the immediate carbon loss following logging (e.g., Pinard and Putz 1996; Gerwing 2002). We made preliminary estimates for the carbon balance of logging at the Tapajos National Forest using field measurements of damage and simple models of decay, regrowth, and off-site carbon loss to predict carbon budgets following logging (Keller et al. 2004b). To account for regrowth following logging, we integrated fluxes over $30 \mathrm{yr}$ assuming single harvesting entries, a new harvested area each year, and simulated regrowth following logging. For a 30-yr integration under RIL management we predicted a loss of $1500 \mathrm{~kg} \mathrm{CO}_{2} \mathrm{ha}^{-1} \mathrm{yr}^{-1}$. It is difficult to compare this loss to the excess trace gas flux following logging because we do not have an estimate for a 30-yr period. If we assume that excess fluxes of $\mathrm{N}_{2} \mathrm{O}$, $\mathrm{CH}_{4}$, and $\mathrm{CO}_{2}$ endure for three years, that is equivalent to assuming that $10 \%$ of the area has an excess flux. Adding the maximum and minimum excess fluxes as $\mathrm{CO}_{2}$ equivalent across both soil types for $\mathrm{N}_{2} \mathrm{O}, \mathrm{CH}_{4}$, and $\mathrm{CO}_{2}$ from Table 6, summing their errors in quadrature and adjusting for $10 \%$ of the area, we get a wide range of outcomes between $633( \pm 338)$ and $30( \pm 1559) \mathrm{kg} \mathrm{CO}_{2} \mathrm{ha}^{-1} \mathrm{yr}^{-1}$. These effects range from trivial to more than one-third of the effect of carbon loss alone. Effects of both trace gases and carbon would be larger for CL.

\section{Conclusions}

Logging causes notable changes to trace gas emissions at a local level. Extrapolation to a region as large and diverse in forest types, soils, and management conditions as the Amazon region of Brazil is impossible from a single site. If 


\section{Earth Interactions • Volume 9 (2005) • Paper No. 23 • Page 25}

similar perturbations happen at other sites, and if these perturbations last for several years, then regional emissions of $\mathrm{N}_{2} \mathrm{O}$ and $\mathrm{CH}_{4}$ from the Brazilian Amazon could be increased by $5 \%-10 \%$. The effect of these emissions in terms of GWP may be as much as one-third as large as the estimated effect of carbon loss from vegetation alone. We note that reduced impact logging (RIL) practices that control harvest damage, especially those that minimize the area of mechanical soil disturbance, will also mitigate excess $\mathrm{N}_{2} \mathrm{O}$ and $\mathrm{CH}_{4}$ fluxes related to logging.

Acknowledgments. We thank two anonymous reviewers for their helpful comments. Michael Palace, Maria Hunter, and Lorena Brewster provided valuable support in data processing, preparation of the figures, and formatting of the bibliography. Barbara Wick, Kadson Oliveira, Cleuton Pereira, and Francisco Alves Freitas Neto assisted with the field collections and laboratory work. We are grateful to the Brazilian Ministry of Science and Technology (MCT) for their leadership of the Large-Scale Biosphere-Atmosphere Experiment in Amazonia (LBA) and to Brazil's Center for Weather Prediction and Climate Studies (CPTEC) and Brazil's National Institute for Amazon Research (INPA) for their management of that program. Johan Zweede and the staff of the Fundação Floresta Tropical provided logistical and managerial support for our field studies. We are grateful to NASA (NCC5-225, NCC5-357, and NAG5-8709), the U.S. Forest Service, and USAID for financial support.

\section{References}

Andreae, M. O., and Coauthors, 2002: Biogeochemical cycling of carbon, water, energy, trace gases, and aerosols in Amazonia: The LBA-EUSTACH experiments. J. Geophys. Res., 107, 8066, doi:10.1029/2001JD000524.

Asner, G. P., M. Keller, and J. M. N. Silva, 2004: Spatial and temporal dynamics of forest canopy gaps following selective logging in the eastern Amazon. Global Change Biol., 10, 1-19.

Bevington, P. R., 1969: Data Reduction and Error Analysis for the Physical Sciences. McGrawHill, $336 \mathrm{pp}$.

Blake, G. R., and K. H. Hartge, 1986: Bulk density. Methods of Soil Analysis, Part 1, Physical and Mineralogical Methods, A. Klute, Ed., Soil Science Society of America, 363-375.

Bollmann, A., and R. Conrad, 1998: Influence of O2 availability on NO and N2O release by nitrification and denitrification in soils. Global Change Biol., 4, 387-396.

Born, M., H. Dorr, and I. Levin, 1990: Methane consumption in aerated soils of the temperate zone. Tellus, 42A, 2-8.

Breuer, L., H. Papen, and K. Butterbach-Bahl, 2000: $\mathrm{N}_{2} \mathrm{O}$ emission from tropical forest soils of Australia. J. Geophys. Res., 105, 26 353-26 367.

Brouwer, C., 1996: Nutrient Cycling in Pristine and Logged Tropical Rain Forest: A Study in Guyana. Elinkwijk, 224 pp.

Conrad, R., 1996: Soil microorganisms as controllers of atmospheric trace gases $\left(\mathrm{H}_{2}, \mathrm{CO}, \mathrm{CH}_{4}\right.$, OCS, $\mathrm{N}_{2} \mathrm{O}$, and NO). Microbiol. Rev., 60, 609-640.

Crill, P. M., 1991: Seasonal patterns of methane uptake and carbon dioxide release by a temperature woodland soil. Global Biogeochem. Cycles, 5, 319-334.

_ Res., 93, 1564-1570.

— M. Keller, A. Weitz, B. Grauel, and E. Veldkamp, 2000: Intensive field measurement of nitrous oxide emissions from a tropical agricultural soil. Global Biogeochem. Cycles, 14, 85-95. 


\section{Earth Interactions • Volume 9 (2005) • Paper No. 23 • Page 26}

Davidson, E. A., and W. Kingerlee, 1997: A global inventory of nitric oxide emissions from soils. Nutrient Cycles Agro-Ecosyst., 48, 37-50.

—, M. Keller, H. E. Erickson, L. V. Verchot, and E. Veldkamp, 2000: Testing a conceptual model of soil emissions of nitrous and nitric oxides. Bioscience, 50, 667-680.

Ewel, J., and L. F. Conde, 1980: Potential ecological impact of increased intensity of tropical forest utilization. Biotrop, Special Publication No. 11, Bogor, Indonesia.

Firestone, M. K., and E. A. Davidson, 1989: Microbial basis of $\mathrm{NO}$ and $\mathrm{N}_{2} \mathrm{O}$ production and consumption in soil. Exchange of Trace Gases between Terrestrial Ecosystems and the Atmosphere, M. O. Andreae and D. S. Schimel, Eds., John Wiley \& Sons, 7-21.

Galbally, I. E., and C. Johansson, 1989: A model relating laboratory measurements of rates of nitric oxide production and field measurements of nitric oxide emission from soils. J. Geophys. Res., 94, 6473-6480.

Garcia-Montiel, D. C., P. A. Steudler, M. C. Piccolo, J. M. Melillo, C. Neill, and C. C. Cerri, 2001: Controls on soil nitrogen oxide emissions from forest and pastures in the Brazilian Amazon. Global Biogeochem. Cycles, 15, 1021-1030.

— J. M. Melillo, P. A. Steudler, and C. Neil, 2002: Relationship between $\mathrm{N}_{2} \mathrm{O}$ and $\mathrm{CO}_{2}$ emission from the Amazon Basin. Geophys. Res. Lett., 29, 1090, doi:10.1029/2001GL013830.

- and Coauthors, 2004: Emissions of $\mathrm{N}_{2} \mathrm{O}$ and $\mathrm{CO}_{2}$ from terra firme forests in Rondonia, Brazil. Ecol. Appl., 14, S214-S220.

Gerwing, J. J., 2002: Degradation of forests through logging and fire in the eastern Brazilian Amazon. For. Ecol. Manage., 157, 131-141.

Holmes, T. P., G. M. Blate, J. C. Zweede, R. Pereira Jr., P. Barreto, F. Boltz, and R. Bauch, 2002: Financial and ecological indicators of reduced impact logging performance in the eastern Amazon. For. Ecol. Manage., 163, 93-110.

Houghton, R. A., D. L. Skole, C. A. Nobre, J. L. Hackler, K. T. Lawrence, and W. H. Chomentowski, 2000: Annual fluxes of carbon from the deforestation and regrowth in the Brazilian Amazon. Nature, 403, 301-304.

Hurlbert, S. H., 1984: Pseudoreplication and the design of ecological field experiments. Ecol. Monogr., 54, 187-211.

Johns, J. S., P. Barreto, and C. Uhl, 1996: Logging damage during planned and unplanned logging operations in the eastern Amazon. For. Ecol. Manage., 89, 59-77.

Keller, M., and W. A. Reiners, 1994: Soil-atmosphere exchange of nitrous oxide, nitric oxide, and methane under secondary succession of pasture to forest in the Atlantic lowlands of Costa Rica. Global Biogeochem. Cycles, 8, 399-410.

- W. A. Kaplan, and S. C. Wofsy, 1986: Emissions of $\mathrm{N}_{2} \mathrm{O}, \mathrm{CH}_{4}$, and $\mathrm{CO}_{2}$ from tropical forest soils. J. Geophys. Res., 91, 11 791-11 802.

— M. E. Mitre, and R. F. Stallard, 1990: Consumption of atmospheric methane in soils of central Panama effects of agricultural development. Global Biogeochem. Cycles, 4, 21-27.

— D. J. Jacob, S. C. Wofsy, and R. C. Harris, 1991: Effects of tropical deforestation on global and regional atmospheric chemistry. Climate Change, 19, 139-158.

—, E. Veldkamp, A. M. Weitz, and W. A. Reiners, 1993: Effect of pasture age on soil trace-gas emissions from a deforested area of Costa Rica. Nature, 365, 244-246.

— A. M. Weitz, B. Bryan, M. M. Rivera, and W. L. Silver, 2000: Soil-atmosphere nitrogen oxide fluxes: Effects of root disturbance. J. Geophys. Res., 105, 17 693-17 698.

- M. Palace, and G. Hurtt, 2001: Biomass estimation in the Tapajos National Forest, Brazil. Estimation of sampling and allometric uncertainties. For. Ecol. Manage., 154, 371-382.

,-- G. P. Asner, R. Pereira, and J. N. M. Silva, 2004a: Coarse woody debris in undisturbed and logged forests in the eastern Brazilian Amazon. Global Change Biol., 10, 784-795.

—, G. P. Asner, J. M. N. Silva, and M. Palace, 2004b: Sustainability of selective logging of upland forests in the Brazilian Amazon: Carbon budgets and remote sensing as tools for evaluation of logging effects. Working Forests in the American Tropics: Conservation 


\section{Earth Interactions • Volume 9 (2005) • Paper No. 23 • Page 27}

Through Sustainable Management? D. J. Zarin et al., Eds., Columbia University Press, 41-63.

Kiese, R., B. Hewett, A. Graham, and K. Butterbach-Bahl, 2003: Seasonal variability of $\mathrm{N}_{2} \mathrm{O}$ emissions and $\mathrm{CH}_{4}$ uptake by tropical rainforest soils of Queensland, Australia. Global Biogeochem. Cycles, 17, 1043, doi:10.1029/2002GB002014.

Levaggi, D., E. L. Kothny, T. Belsky, E. de Vera, and P. K. Mueller, 1974: Quantitative analysis of nitric oxide in the presence of nitrogen dioxide at atmospheric concentrations. Environ. Sci. Technol., 8, 348-350.

Linn, D. M., and J. W. Doran, 1984: Effect of water-filled pore space on carbon dioxide and nitrous oxide production in tilled and nontilled soils. Soil Sci. Soc. Amer. J., 48, 1267-1272.

Luizão, F., P. Matson, G. Livingston, R. Luizão, and P. M. Vitousek, 1989: Nitrous oxide flux following tropical land clearing. Global Biogeochem. Cycles, 3, 281-285.

Matson, P. A., and P. M. Vitousek, 1990: Ecosystem approach for the development of a global nitrous oxide budget: Processes that regulate gas emissions vary in predictable ways. Bioscience, 40, 667-672.

McNabb, K. L., M. S. Miller, B. G. Lockaby, B. J. Stokes, R. G. Clawson, J. A. Stanturf, and J. N. M. Silva, 1997: Selection harvests in Amazonian rainforests: long-term impacts on soil properties. For. Ecol. Manage., 93, 153-160.

Melack, J. M., L. L. Hess, M. Gastil, B. R. Forsberg, S. K. Hamilton, I. B. T. Lima, and M. L. M. Novo, 2004: Regionalizations of methane emissions in the Amazon basin with microwave remote sensing. Global Change Biol., 10, 530-544.

Melillo, J. M., P. A. Steudler, B. J. Feigl, C. Neill, D. Garcia, M. C. Piccolo, C. C. Cerri, and H. Tian, 2001: Nitrous oxide emissions from forests and pastures of various ages in the Brazilian Amazon. J. Geophys. Res., 106, 34 179-34 188.

Neill, C., M. C. Piccolo, P. A. Steudler, J. M. Mellilo, B. J. Feigl, and C. C. Cerri, 1995: Nitrogen dynamics in soils of forests and active pastures in the western Brazilian Amazon basin. Soil Biol. Biochem., 27, 1167-1175.

—, P. A. Steudler, D. C. Garcia-Montiel, J. M. Melillo, B. J. Feigl, M. C. Piccolo, and C. C. Cerri, 2005: Rates and controls of nitrous oxide and nitric oxide emissions following conversion of forest to pasture in Rondonia. Nutrient Cycling Agroecosys., 71, 1-15.

Nepstad, D. C., and Coauthors, 1999: Large-scale impoverishment of Amazonian forests by logging and fire. Nature, 398, 505-508.

Parsons, W. F. J., M. E. Mitre, M. Keller, and W. A. Reiners, 1993: Nitrate limitation of N2O production and denitrification from tropical pasture and rain forest soils. Biogeochemistry, 22, 170-193.

Pereira, R., J. C. Zweede, G. P. Asner, and M. M. Keller, 2002: Forest canopy damage and recovery in reduced impact and conventional logging in eastern Para, Brazil. For. Ecol. Manage., 168, $77-89$.

Pinard, M. A., and F. E. Putz, 1996: Retaining forest biomass by reducing logging damage. Biotropica, 28, 278-295.

Ramaswamy, V., and Coauthors, 2001: Radiative forcing of climate change. Climate Change 2001: The Scientific Basis: Contribution of Working Group I to the Third Assessment Report of the Intergovernmental Panel on Climate Change, J. T. Houghton et al., Eds., Cambridge University Press, 349-416 pp.

Rayment, M. B., and P. G. Jarvis, 1997: An improved open chamber system for measuring soil $\mathrm{CO}_{2}$ effluxes in the field. J. Geophys. Res., 102, 28 779-28 784.

Rummel, U., C. Ammann, A. Gut, F. X. Meixner, and M. O. Andreae, 2002: Eddy covariance measurements of nitric oxide flux within an Amazonian rain forest. J. Geophys. Res., 107, 8050, doi:10.1029/2001JD000520.

Saleska, S. R., and Coauthors, 2003: Carbon in Amazon forests: Unexpected seasonal fluxes and disturbance-induced losses. Science, 302, 1554-1557.

Scatena, F. N., S. Moya, C. Estrada, and J. D. Chinea, 1996: The first five years in the reorgani- 


$$
\text { Earth Interactions - Volume } 9 \text { (2005) - Paper No. } 23 \text { • Page } 28
$$

zation of aboveground biomass nutrient use following hurricane Hugo in the Bisley Experimental Watersheds, Luquillo Experimental Forest, Puerto Rico. Biotropica, 28, 424-440.

Silver, W. L., J. Neff, M. McGroddy, E. Veldkamp, M. Keller, and R. Cosme, 2000: Effects of soil texture on belowground carbon and nutrient storage in a lowland Amazonian forest ecosystem. Ecosystems, 3, 193-209.

Steudler, P. A., J. M. Melillo, B. J. Feigl, C. Neill, M. C. Piccolo, and C. C. Cerri, 1996: Consequences of forest-to-pasture conversion on $\mathrm{CH}_{4}$ fluxes in the Brazilian Amazon basin. J. Geophys. Res., 101, 18 547-18 554.

Varner, R. K., M. Keller, J. R. Robertson, J. D. Dias, H. Silva, P. M. Crill, M. McGroddy, and W. L. Silver, 2003: Experimentally induced root mortality increased nitrous oxide emissions from tropical forest soils. Geophys. Res. Lett., 30, 1144, doi:10.1029/2002GL016164.

Veldkamp, E., and M. Keller, 1997: Nitrogen oxide emissions from a banana plantation in the humid Tropics. J. Geophys. Res., 102, 15 889-15 898.

Verchot, L. V., E. A. Davidson, J. H. Cattanio, I. L. Ackerman, H. E. Erickson, and M. Keller, 1999: Land use change and biogeochemical controls of nitrogen oxide emissions from soils in eastern Amazonia. Global Biogeochem. Cycles, 13, 31-46.

Verissimo, A., P. Barreto, M. Mattos, R. Tarifa, and C. Uhl, 1992: Logging impacts and prospects for sustainable forest management in an old Amazonian frontier: The case of Paragominas. For. Ecol. Manage., 55, 169-199.

Earth Interactions is published jointly by the American Meteorological Society, the American Geophysical Union, and the Association of American Geographers. Permission to use figures, tables, and brief excerpts from this journal in scientific and educational works is hereby granted provided that the source is acknowledged. Any use of material in this journal that is determined to be "fair use" under Section 107 or that satisfies the conditions specified in Section 108 of the U.S. Copyright Law (17 USC, as revised by P.IL. 94-553) does not require the publishers' permission. For permission for any other form of copying, contact one of the copublishing societies. 